\title{
Article \\ Effects of Combined Aerosolization with Ultraviolet C Light-Emitting Diode on Enterohemorrhagic Escherichia coli and Staphylococcus aureus Attached to Soft Fresh Produce
}

\author{
Chae-Lim Lee, Geun-Hyang Kim and Ki-Sun Yoon *D
}

Citation: Lee, C.-L.; Kim, G.-H.; Yoon, K.-S. Effects of Combined Aerosolization with Ultraviolet C Light-Emitting Diode on Enterohemorrhagic Escherichia coli and Staphylococcus aureus Attached to Soft Fresh Produce. Foods 2021, 10, 1834. https://doi.org/10.3390/ foods10081834

Academic Editors: Panagiotis

Skandamis and Anastasia

Kapetanakou

Received: 29 June 2021

Accepted: 6 August 2021

Published: 8 August 2021

Publisher's Note: MDPI stays neutral with regard to jurisdictional claims in published maps and institutional affiliations.

Copyright: (c) 2021 by the authors. Licensee MDPI, Basel, Switzerland. This article is an open access article distributed under the terms and conditions of the Creative Commons Attribution (CC BY) license (https:/ / creativecommons.org/licenses/by/ $4.0 /$ )
Department of Food and Nutrition, College of Human Ecology, Kyung Hee University, Dongdaemun-gu, Seoul 02447, Korea; cr195@khu.ac.kr (C.-L.L.); dytnfvos@naver.com (G.-H.K.)

* Correspondence: ksyoon@khu.ac.kr; Tel.: +82-2-961-0264

\begin{abstract}
Washing soft fresh produce such as strawberries, baby leaves, and sliced onions with sanitizing agents is challenging due to their fragile texture. Thus, treatments like aerosolization using slightly acidic electrolyzed water (SAEW) and ultraviolet $C$ light-emitting diode (UVC LED) irradiation may be good alternatives. In the present study, the reduction effects of a combined treatment of aerosolization using SAEW and UVC LED irradiation on enterohemorrhagic Escherichia coli (EHEC) and Staphylococcus aureus attached to strawberries, baby leaves, and sliced onions were investigated. The behaviours of EHEC and S. aureus, moisture loss, colour measurement, and visual appearance were also analyzed at 10 and $15{ }^{\circ} \mathrm{C}$ for 7 days. The reduction effect of the combined treatment with 100 SAEW and UVC LED was higher (0.53-0.92 log CFU g $\left.{ }^{-1}\right)$ than a single aerosolization treatment $\left(0.11-0.41 \log \mathrm{CFU} \mathrm{g}{ }^{-1}\right)$, regardless of samples or pathogens. A greater effect on EHEC and S. aureus reduction was observed in strawberries $\left(0.74\right.$ and $\left.0.92 \log \mathrm{CFU} \mathrm{g}^{-1}\right)$ than in baby leaves $\left(0.62\right.$ and $\left.0.53 \log \mathrm{CFU} \mathrm{g}{ }^{-1}\right)$ and sliced onions $\left(0.55\right.$ and $\left.0.62 \log \mathrm{CFU} \mathrm{g}{ }^{-1}\right)$. The combined treatment further reduced the EHEC and $S$. aureus populations in strawberries during 7 days of storage at 10 and $15^{\circ} \mathrm{C}$. However, the EHEC and S. aureus populations were maintained in baby leaves and sliced onions at $10^{\circ} \mathrm{C}$ for 7 days. Additionally, the greatest effect on the maintenance of colour and appearance was obtained in the combined treatment. Since the combined treatment reduces EHEC and S. aureus populations and preserves visual quality, it could be expected to extend the shelf life of soft fresh produce at the retailer stage of the supply chain.
\end{abstract}

Keywords: slightly acidic electrolyzed water (SAEW); pathogen populations; reduction effect; moisture loss; visual quality

\section{Introduction}

The fresh-cut produce market has increased drastically to meet consumer demand for healthy and ready-to-eat foods. The production of fresh-cut produce showed an increase of $64.8 \%$ from 2013 to 2017 in Korea [1]. Likewise, the market for meal kits is also on the rise, since the meal kit industry was valued at 4.65 billion US dollars in 2017, representing a 300\% growth in the United States [2]. Both fresh-cut produce and some meal kit products consist of various vegetables that can be consumed as non-processed produce.

A total of 515 cases and six deaths due to foodborne outbreaks were reported in the United States from 2011 to 2020 due to enterohemorrhagic Escherichia coli (EHEC) in fresh produce [3-5]. Specifically, 165 cases and 2 deaths due to EHEC in a salad were reported in 2016 in the UK and 235 cases due to EHEC in onion were reported in 2008 in Canada [6,7]. In Korea, Staphylococcus aureus has been regularly detected in fresh and fresh-cut produce at the market. S. aureus was detected in 1 out of 181 baby-leaf vegetables $(0.6 \%)$ [8], four out of 60 tomatoes $(6.7 \%)$, one out of 60 mandarins (1.7\%) [9], six out of 390 fresh ready-to-eat food $(1.5 \%)$ [10], one out of 150 lettuces $(0.7 \%)$, two out of 150 cabbages $(1.3 \%)$, and one out of 150 celeries $(0.7 \%)$ [11]. 
The sanitizing step in preparing fresh produce is essential to reduce the risk of foodborne illness. Washing soft fruits, baby leaves, and sliced onions might lead to the loss of their commercial value due to changes in shape and appearance because they have fragile structures. They may have a higher microbial growth incidence after the postharvest period without a washing step [12-16]. Aerosolization of sanitizers could reduce the population of foodborne pathogens on soft fresh produce at the market [17-20]. Aerosols are defined as clumps of solid or liquid particles dispersed in the air, typically from 0.001 to $100 \mu \mathrm{m}$ in size. Thus, aerosolization converts sanitizer into fine mist particles, and it could be applied to disinfect produce with fragile structures in its surfaces.

Ultraviolet (UV) light is a non-thermal method of disinfection that induces the formation of pyrimidine dimers in the DNA and RNA of a microorganism, thus interfering with DNA replication and ultimately leading to cell death [21,22]. UV irradiation is used with low-pressure mercury (LPM) lamps which contain glass and mercury, which represent both physical and chemical hazards in food production environments [23]. The Minamata Convention on Mercury treaty also prohibits the manufacture, import, and/or export of mercury-containing products [24]. In this sense, ultraviolet C light-emitting diodes (UVC LED) could compensate for the several limitations of LPM lamps. Some advantages of UVC LED include their small size, robustness, lack of mercury, long lifetime, no pre-heating, and the ability to operate effectively at cold temperatures [25-27]. It has been shown that UVC LED can effectively reduce pathogen populations in fresh-cut produce [28].

Several studies have also investigated the effects of aerosolization, UV LED, or UVC LED on reducing bacteria populations in food [17,19,29-32]. Jiang et al. [17] suggested an in-package aerosolization technology to improve the microbial safety of cherry tomatoes against Salmonella spp. Aerosolized malic acid was also suggested as an alternative sanitizer to increase the microbial safety of fresh produce such as spinach and lettuce [19]. The combined effect of slightly acidic electrolyzed water (SAEW) and UV LED has better decontamination efficiency against Salmonella spp. and E. coli in coriander than a single treatment [29]. An inactivation effect of UVC LED treatment on E. coli O157:H7, S. Typhimurium, and L. monocytogenes inoculated onto sliced deli meat, spinach surface [30] and sliced cheese [32] were reported. However, the combined effect of the aerosolization of malic acid and UVC on the inactivation of pathogens in fresh-cut lettuce was only reported by Seong et al. [31]. As far as we know, the combined effect of aerosolization using SAEW and UVC LED for soft fresh produce has not been reported yet. Therefore, the main objectives of this study were (1) to investigate the efficacy of the combined treatment of aerosolization using SAEW and UVC LED $(275 \mathrm{~nm})$ in order to reduce bacteria on soft fresh produce, including strawberries, baby leaves, and sliced onions, and (2) to determine the applicability of combined treatment on an industrial scale through the evaluation of quality.

\section{Materials and Methods}

\subsection{Bacteria Strains}

Enterohemorrhagic Escherichia coli (EHEC) strains, including E. coli O157:H7 (NCTC 12079) and non-O157 enterohemorrhagic E. coli (NCCP 13720, 13721), were obtained from the Ministry of Food and Drug Safety (MFDS) in Korea. Enterotoxin A-producing S. aureus (SEA; ATCC 13565) was purchased from American Type Culture Collection (ATCC). Enterotoxin G and I-producing S. aureus and non-enterotoxin-producing S. aureus were isolated from red cabbage and pineapple, respectively, which were obtained at the market. Each stock culture of EHEC and S. aureus was maintained at $-80^{\circ} \mathrm{C}$ in tryptic soy broth (TSB, MBcell, Seoul, Korea) containing 20\% glycerol.

\subsection{Culture Preparation}

Each strain of EHEC and S. aureus was cultured in $10 \mathrm{~mL}$ of sterile TSB and incubated at $36{ }^{\circ} \mathrm{C}$ for $24 \mathrm{~h}$ in a rotary shaker (VS-8480SP, Vision, Daejeon, Korea) at $140 \mathrm{rpm}$. To prepare cocktail cultures of each bacterium, an equal quantity of each strain was combined and added into a sterilized $50 \mathrm{~mL}$ conical tube (SPL Life Science, Pocheon, Korea). For 
the bacterial inoculum solution, the cocktail suspension was serially diluted 10-fold with $0.1 \%$ peptone water (PW, Difco, Detroit, MI, USA). Then, $10 \mathrm{~mL}$ of the diluted cocktail suspension was mixed with $990 \mathrm{~mL}$ of sterile $0.1 \% \mathrm{PW}$ in a sterile beaker of $2 \mathrm{~L}$.

\subsection{Sample Preparation and Inoculation}

A pack of baby leaves $(150 \mathrm{~g})$, strawberries ( $500 \mathrm{~g})$, and a bag of onion (5 onions) were purchased from the supermarket (Seoul, Korea) for each experiment. Each pack of baby leaves consisted of a mix of tatsoi, bok choy, and radish sprouts. All samples were visually selected and stored at $4{ }^{\circ} \mathrm{C}$ until use. To remove indigenous microorganisms, baby leaves were submerged in $3.6 \%$ hydrogen peroxide for $5 \mathrm{~min}$, according to the protocol described by Kim et al. [33], rinsed with tap water for $2 \mathrm{~min}$, and then exposed to UVC LPM lamp irradiation for $30 \mathrm{~min}$. After removing indigenous microorganisms, $100 \mathrm{~g}$ of baby leaves were dipped into a bacterial inoculum solution by stirring with a sterile magnetic stir bar for $2 \mathrm{~min}$. These inoculated samples were air-dried on a sterile stainless-steel tray under an aseptic bench for $30 \mathrm{~min}$. To prepare sliced onions, onions were peeled and aseptically cut into slices with a stainless-steel knife and then dipped in a bacterial inoculum solution in the same way as the baby leaf vegetables. Approximately $10 \mathrm{~g}$ of each strawberry was hulled and washed with tap water. A total of $100 \mu \mathrm{L}$ of prepared cocktail suspensions was spot inoculated onto strawberries and air-dried in a sterile stainless-steel tray under an aseptic bench for $30 \mathrm{~min}$. After the air-drying process, $100 \mathrm{~g}$ of each sample was transferred to a new sterile stainless tray for aerosolization treatment with sanitizers.

The initial inoculum levels of strawberries, sliced onions, and baby leaves were 5-6 $\log$ CFU g ${ }^{-1}$.

\subsection{Microbial Reduction Procedure of Soft Fresh Produce}

\subsubsection{Procedure of Aerosolization Treatment with Sanitizers}

Sodium hypochlorite (100 NaClO, Hanson Hygiene Co., Cheonan-si, Korea) solution at $100 \mathrm{ppm}$ was prepared according to the manufacturer's instructions. Both $60 \mathrm{ppm}$ of slightly acidic electrolyzed water (60 SAEW) and 100 ppm of SAEW (100 SAEW) were provided by Cosmic Round Korea Co., Seongnam, Korea. The $\mathrm{pH}$ and available chlorine concentrations of sanitizers were measured with a $\mathrm{pH}$ meter (Orion-star $\mathrm{pH}-$-benchtop, Thermo, Waltham, MA, USA) and chlorine test papers (Toyo Roshi Kaisha, Ltd., Tokyo, Japan), respectively.

The aerosolization test chamber was made of $5 \mathrm{~mm}$-thick clear acryl sheets $(460 \times$ $460 \times 300 \mathrm{~mm}$ ). The chamber was sealed, and aerosolized mist was generated using an ultrasonic nebulizer (402 AI, Yuwell Medical Equipment \& Supply Corp., Suzhou, China). The aerosolized mist was transferred from the machine through a tube to the lid of the chamber. The nebulizer could atomize sanitizers into droplets with a diameter of approximately 3.9 to $5 \mu \mathrm{m}$. Inoculated samples were treated with aerosolized sanitizers for $10 \mathrm{~min}$ in the chamber. After the treatment, the samples were transferred to an aseptic bench and air-dried for $30 \mathrm{~min}$.

\subsubsection{Procedure of Ultraviolet $C$ Light-Emitting Diode (UVC LED) Irradiation Treatment}

A total of ten ultraviolet $C$ light-emitting diode (UVC LED) modules (Bluelumi, Yongin-si, Korea) were set in a chamber $(500 \times 400 \times 520 \mathrm{~mm})$ equipped with two PCBs. Five UVC LED chips ( $275 \mathrm{~nm}$ wavelength) were linearly connected on an electronic printed circuit board (PCB; $450 \times 25 \mathrm{~mm}$ ). UVC LED irradiation was performed at a distance of $6 \mathrm{~cm}$ between the UVC LED and the samples used in the present study. The irradiance intensity of the UVC LED module was measured with a spectrometer (UVC-254SD, Lutron Electronics Co., Inc., Coopersburg, PA, USA) previously calibrated at a range of $240-390 \mathrm{~nm}$. The UVC radiation intensity was $173 \mu \mathrm{Wcm}^{-2}$.

Aerosolized and air-dried soft fresh produce (strawberries, baby leaves, and sliced onions, $10 \mathrm{~g}$ each) were transferred to polyethylene terephthalate (PET) containers (DA- 
0604, Modenpojang, Seoul, Korea). Thus, each sample was placed in the UVC LED chamber and was irradiated for 3 min with UVC LED doses of $31.14 \mathrm{~mJ} \mathrm{~cm}^{-2}$.

\subsection{Microbial Analysis}

Treated soft fresh produce $(10 \mathrm{~g})$ was transferred into a sterile stomacher bag (JS-011, Jinsung Uni-Tech Co., Ltd., Goyang-si, Korea) and homogenized with $90 \mathrm{~mL}$ of sterile $0.1 \%$ peptone water (PW, Becton, Dickinson and Company, Sparks, NV, USA) using a stomacher (BagMixer, Interscience, St Nom la Bretêche, France) for $2 \mathrm{~min}$. The homogenized solution was serially diluted 10 -fold with sterile $0.1 \% \mathrm{PW}$ and spread onto non-selective and selective agar plates for each pathogen. Eosin methylene blue agar (EMB, Oxoid, Hampshire, UK) and Baird-Parker agar bases (BPA, MBcell, Seoul, Korea) were used as selective media to enumerate EHEC and $S$. aureus populations, respectively. Tryptic soy agar (TSA, MBcell, Seoul, Korea) was used to enumerate both EHEC and S. aureus populations as a non-selective medium. Plates were incubated for $24-48 \mathrm{~h}$ at $37^{\circ} \mathrm{C}$. Every bacterial growth enumeration was based on duplicate counts.

\subsection{Quality Evaluation during Storage at 10 and $15^{\circ} \mathrm{C}$ after the Combined Treatment}

2.6.1. Behaviors of EHEC and S. aureus on Soft Fresh Produce during Storage

Behaviors of EHEC and S. aureus were compared among samples, including samples not washed with sanitizer (controls), samples treated with aerosolization at 100 ppm SAEW (100 SAEW), and samples treated with aerosolization at $100 \mathrm{ppm}$ and irradiated with UVC LED for $3 \mathrm{~min}$ (100 SAEW + UVC LED). Each sample (10 g) was collected into a PET container with a lid and stored for 7 days at 10 (storage temperature) and $15^{\circ} \mathrm{C}$ (abused temperature). EHEC and S. aureus populations were enumerated at intervals of $24 \mathrm{~h}$ during the 7-day period using the selective media.

\subsubsection{Moisture Loss Analysis}

Moisture losses of control and treated (100 SAEW, 100 SAEW + UVC LED) samples were measured every $24 \mathrm{~h}$ during the 7 days of storage at 10 and $15^{\circ} \mathrm{C}$. This parameter was calculated as the difference between the initial weight and the weight at the sampling date using the following formula:

Moisture loss $(\%)=($ initial weight - sampling date weight $) /$ initial weight $\times 100$

\subsubsection{Colour Measurement and Visual Appearance Evolution}

The colour of each sample was measured every $24 \mathrm{~h}$ during the 7 days of storage at 10 and $15{ }^{\circ} \mathrm{C}$ using a colorimeter (Minolta CR-400, Osaka, Japan). The colour was described as coordinates: $L^{*}, a^{*}$, and $b^{*}$ colour values. The $L^{*}$ parameter shows lightness to darkness evolution. It ranges from 0 (black) to 100 (white). The $a^{*}$ parameter measures the degree of redness $\left(+a^{*}\right)$ or greenness $\left(-a^{*}\right)$. The $b^{*}$ parameter measures the degree of yellowness $\left(+b^{*}\right)$ or blueness $\left(-b^{*}\right)$. The evolution of the visual appearance of controls and treated (100 SAEW, 100 SAEW+UVC LED) samples were photographed daily for 7 days at 10 and $15^{\circ} \mathrm{C}$. The most distinct changes of each sample's properties that were observed include browning and molding in strawberries, yellowing and softening of baby leaves, and browning and dryness of sliced onions.

\subsection{Statistical Analysis}

All experiments were repeated twice, with three replicates per treatment. Statistical analyses were conducted with Statistical Analysis System (SAS) version 9.4 (SAS Institute Inc., Cary, NC, USA). Statistical comparisons for more than two groups were performed using one-way analysis of variance (ANOVA) followed by Duncan's test for multiple range tests. A value of $p<0.05$ was considered statistically significant. 


\section{Results and Discussion}

3.1. Effect of Aerosolization Alone and Combined Treatment with UVC LED on the Reduction in EHEC and S. aureus

The effects of aerosolization with 60 SAEW, 100 SAEW, or $100 \mathrm{NaClO}$ and combined treatment of 100 SAEW and UVC LED on the reduction in EHEC and S. aureus attached to strawberries, baby leaves, and sliced onions were compared (Figure 1). Among single treatments used for aerosolization, the 100 SAEW was the most effective in reducing the microbial population of two pathogens in all three soft fresh produce. The highest reduction (0.34-0.55 $\log$ CFU g ${ }^{-1}$ ) of EHEC populations was observed after treatment with 100 SAEW, followed by that with $100 \mathrm{NaClO}\left(0.24-0.33 \mathrm{log}_{\mathrm{CFU} \mathrm{g}}{ }^{-1}\right)$ and 60 SAEW treatment (0.14-0.26 $\log \mathrm{CFU} \mathrm{g}{ }^{-1}$ ) (Figure 1a). The highest reduction (0.28-0.41 $\log \mathrm{CFU} \mathrm{g}{ }^{-1}$ ) of $S$. aureus populations was also observed after treatment with 100 SAEW, followed similarly by that with $100 \mathrm{NaClO}\left(0.17-0.26 \log \mathrm{CFU} \mathrm{g}{ }^{-1}\right)$ and 60 SAEW treatment (0.11-0.27 log CFU g ${ }^{-1}$ ) (Figure 1b).

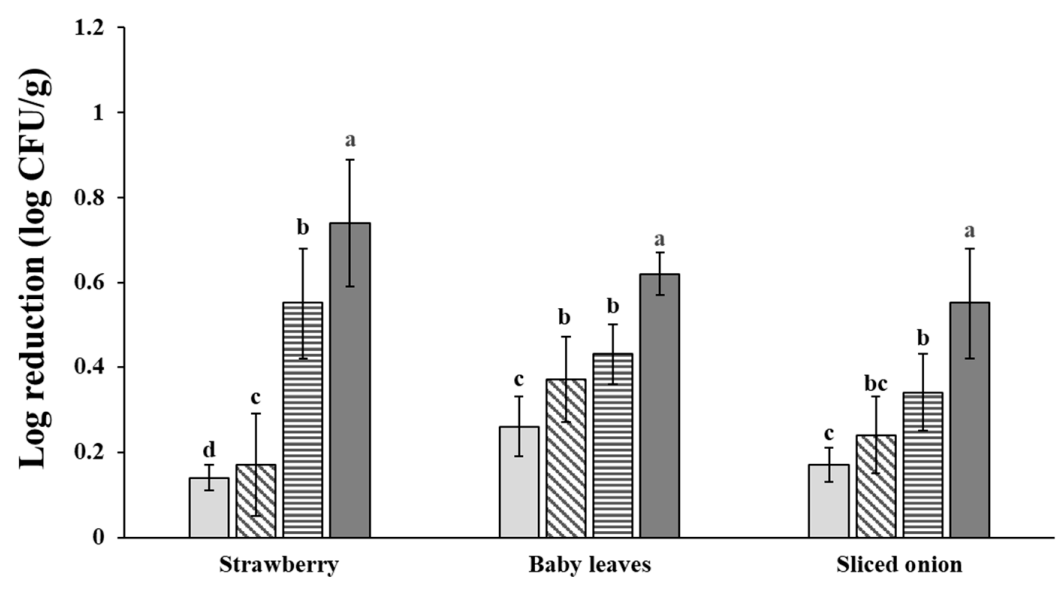

(a)

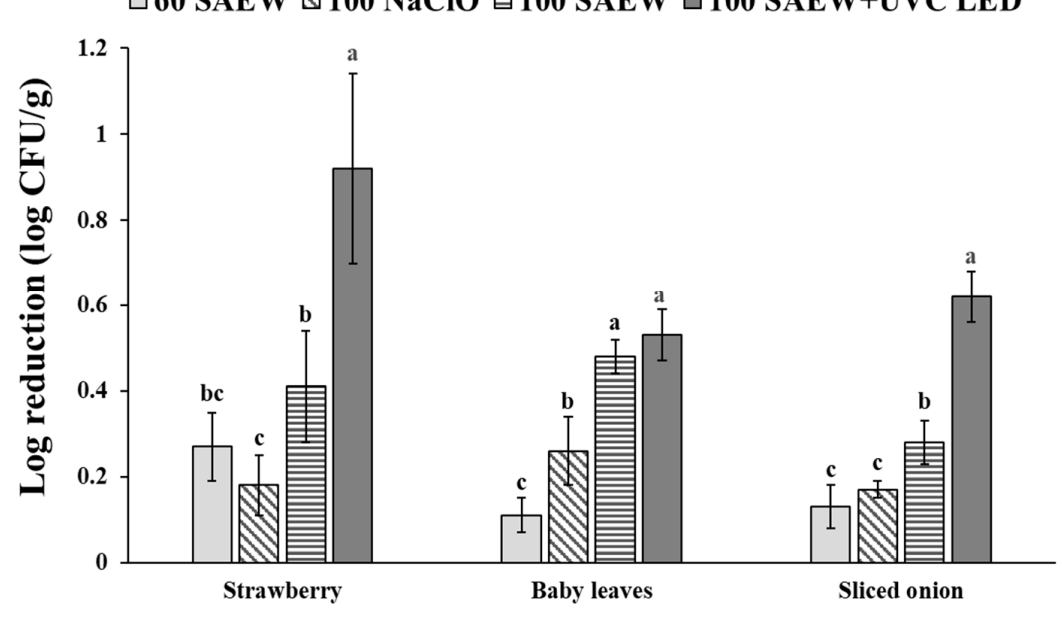

(b)

Figure 1. Comparison of log reduction in aerosolization alone and combined treatments with UVC LED on (a) enterohemorrhagic E. coli (EHEC) and (b) S. aureus in strawberry, baby leaves, and sliced onion. 60 SAEW, aerosolization with 60 ppm SAEW; $100 \mathrm{NaClO}$, aerosolization with 100 ppm NaClO; 100 SAEW, aerosolization with 100 ppm SAEW; 100 SAEW + UVC LED, aerosolization with 100 ppm SAEW and radiated UVC LED $(275 \mathrm{~nm})$ for $3 \mathrm{~min} .{ }^{\mathrm{a}-\mathrm{d}}$ Different letters represent significant differences measured by Duncan's multiple tests among treatments within each soft fresh produce at $p<0.05$. 
Cho et al. [34] reported that the aerosolization of carrots with 100, 200, 300, and 400 ppm chlorine dioxide $\left(\mathrm{ClO}_{2}\right)$ for 10 min could reduce E. coli O157:H7 populations by $0.2-1.1 \log \mathrm{CFU} \mathrm{g}^{-1}$, Salmonella Typhimurium by $0.2-1.4 \log \mathrm{CFU} \mathrm{g}^{-1}$, and L. monocytogenes by $0.2-1.2 \mathrm{log}$ CFU g ${ }^{-1}$. Aerosolization of spinach with $400 \mathrm{ppm}$ peracetic acid solution for $15 \mathrm{~min}$ could achieve $0.97 \pm 0.30 \log \mathrm{CFU} \mathrm{g}{ }^{-1}, 1.02 \pm 0.23 \log \mathrm{CFU} \mathrm{g}^{-1}$, and $0.92 \pm 0.20 \log$ CFU g ${ }^{-1}$ reductions for E. coli O157:H7, Salmonella Typhimurium, and L. monocytogenes, respectively [35]. After aerosolization with $2 \%$ malic acid for $10 \mathrm{~min}$, populations of L. monocytogenes, Salmonella Typhimurium, and E. coli O157:H7 populations were reduced by $0.72,0.66,1.03 \log \mathrm{CFU} \mathrm{g}^{-1}$ in spinach and $0.83,1.02,1.35 \log \mathrm{CFU} \mathrm{g}^{-1}$ in lettuce, respectively [19].

Generally, the reduction effect of aerosolization was lower than that of the dipping treatment commonly used to reduce the microbial population. Even when a lower concentration (ppm) and less washing time were applied, the dipping treatment showed a greater reduction effect than aerosolization. The $S$. aureus population was reduced by $1.42-1.65 \log$ CFU g ${ }^{-1}$ when iceberg lettuce, chicory, and cabbage were immersed in 30 ppm SAEW for $5 \mathrm{~min}$ [36]. When carrot, celery, cabbage, and paprika were immersed in $100 \mathrm{ppm} \mathrm{NaClO}$ for $3 \mathrm{~min}, E$. coli and S. aureus populations were reduced by 0.90-1.34 $\log$ CFU g ${ }^{-1}$ and $0.58-1.70 \log$ CFU g ${ }^{-1}$, respectively [28]. Since aerosolization technology could be applied to produce with a soft texture that is difficult to clean [17], the concentration of sanitizer is generally increased to improve the reduction effect of aerosolization $[17,34,35]$. However, a high concentration of sanitizer could lead to consumers' concerns due to its impact on the environment. Thus, incorporating another effective tool with the aerosolization of a sanitizer with a low concentration $(<100 \mathrm{ppm})$ is needed for fragile produce, such as baby leaves and berries.

In this study, the combined treatment of 100 SAEW and UVC LED was more effective in reducing the populations of EHEC and S. aureus in strawberries than in baby leaves or sliced onions. The combined treatment of 100 SAEW and UVC LED reduced EHEC in strawberries, baby leaves, and sliced onions by $0.74 \pm 0.15,0.62 \pm 0.05$, and $0.55 \pm 0.13 \log \mathrm{CFU} \mathrm{g}^{-1}$, respectively (Figure 1a). These combined treatments reduced S. aureus populations in strawberries, baby leaves, and sliced onions by $0.92 \pm 0.22$, $0.53 \pm 0.06$, and $0.62 \pm 0.06 \log \mathrm{CFU} \mathrm{g}{ }^{-1}$, respectively (Figure $1 \mathrm{~b}$ ). A greater reduction was observed for $S$. aureus than for EHEC in strawberries and sliced onions, whereas the reduction was significantly higher for EHEC than S. aureus in baby leaves (Figure 1). The results show that the combined treatment of 100 SAEW and UVC LED had a more efficient bactericidal effect than a single aerosolization treatment. In Korea, 84\% of food manufacturing and processing industries use $\mathrm{NaClO}$ as a sanitizer, and dipping in 100 ppm $\mathrm{NaClO}$ solution for $5 \mathrm{~min}$ is the most commonly used method to sanitize fresh produce [37]. In this work, no significant difference in EHEC or $S$. aureus reduction was observed between dipping in 100 ppm $\mathrm{NaClO}$ for $5 \mathrm{~min}$ and the combined treatment of 100 SAEW and UVC LED treatment (data not shown). According to previous studies [29,31,38,39], combined treatment of washing methods with UVC LED or UVC LPM lamps could result in a more effective reduction in foodborne pathogens in fresh produce. Jiang et al. [29] revealed that a combined treatment of 60 ppm SAEW for $5 \mathrm{~min}$ with UV LED $\left(240 \mu \mathrm{Wcm}^{-2}\right.$ at $6 \mathrm{~cm}$ distance) for coriander reduced Salmonella spp. and E. coli populations by $2.42-2.72 \log \mathrm{CFU} \mathrm{g}^{-1}$. This combined treatment was more effective than a single treatment with SAEW washing or UV LED, which reduced Salmonella spp. and E. coli populations by 1.8-1.85 log CFU g ${ }^{-1}$ and 1.1-1.2 $\log \mathrm{CFU} \mathrm{g}^{-1}$, respectively. Combined treatment of aerosolization with $2 \%$ malic acid for $20 \mathrm{~min}$ and UVC irradiation $(254 \mathrm{~nm})$ for $30 \mathrm{~min}$ was also more effective in reducing pathogen populations than a single treatment [31]. After combined treatment, populations of E. coli O157:H7, Salmonella Typhimurium, and L. monocytogenes in fresh-cut lettuce were reduced 1.65, 1.01, and $1.06 \log C F U ~ g^{-1}$, respectively. In contrast, their populations after a single treatment of aerosolization with $2 \%$ malic acid or UVC irradiation were reduced to $1.10,0.53$, and 0.70 or $1.22,0.72$, and $1.01 \log C F U g^{-1}$, respectively. The population of Salmonella spp. in lettuce was reduced by $2.97 \mathrm{log}$ CFU g ${ }^{-1}$ after combined treatment 
of 80 ppm SAEW dipping for $2 \mathrm{~min}$ and UVC LED with conditions of $100 \mu \mathrm{Wcm}^{-2}$ at $6 \mathrm{~cm}$ distance [38]. The effect of the combined treatment was greater than that of a single treatment with SAEW washing (1.42 $\log$ CFU g ${ }^{-1}$ reduction) or with UVC LED alone (1.58 $\log \mathrm{CFU} \mathrm{g}{ }^{-1}$ reduction). In addition, combined treatment of $50 \mathrm{ppm} \mathrm{ClO}_{2}$ dipping for 5 min with UVC irradiation ( $254 \mathrm{~nm}$ ) was more effective in reducing E. coli O157:H7 and Salmonella Typhimurium in romaine lettuce and kale than single treatments [39]. These results indicate that UVC LED is more effective when it is combined with other washing treatments. Thus, it could be used as another hurdle technology combined with other sanitizers in the fresh produce industry.

3.2. Effect of Combined Treatment of Aerosolization with UVC LED on Behaviours of EHEC and S. aureus in Soft Fresh Produce during Storage at 10 and $15^{\circ} \mathrm{C}$

The effects of control, 100 SAEW, and 100 SAEW with UVC LED on populations of EHEC and S. aureus were investigated after storage at 10 and $15^{\circ} \mathrm{C}$ for 7 days (Figures 2 and 3). No extra wash with a sanitizer was used for comparison as a control.

Strawberry

Baby leaves

Sliced onion
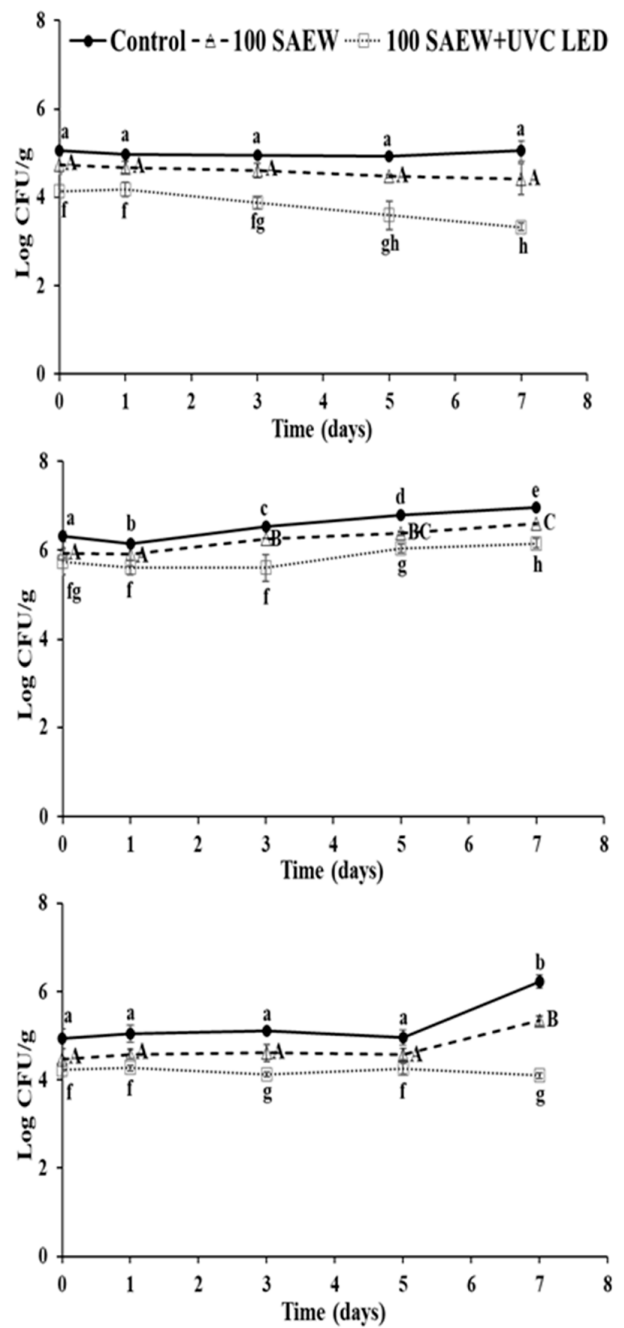

(a)
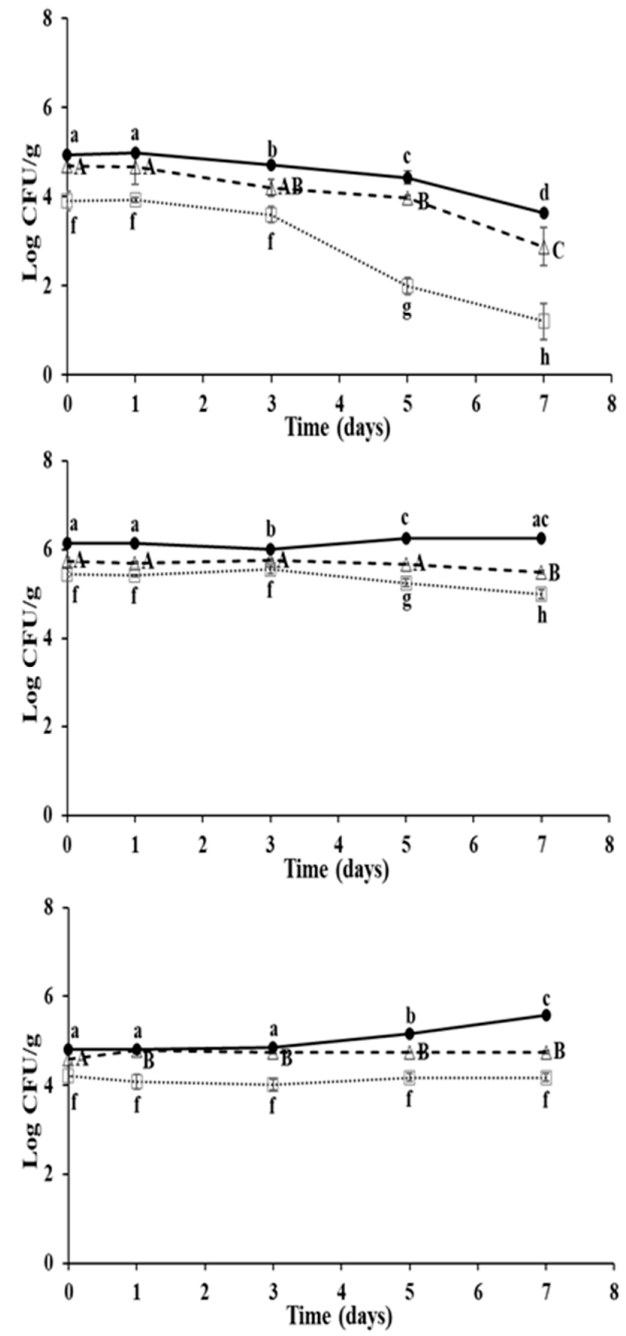

(b)

Figure 2. Log number of enterohemorrhagic E. coli (EHEC) (a) and S. aureus (b) after treatment in strawberry, baby leaves, and sliced onion stored for 7 days at $10^{\circ} \mathrm{C}$. $\bullet$, no extra wash with sanitizer (control); $\triangle$, aerosolization with 100 ppm SAEW (100 SAEW); $\square$, aerosolization with 100 ppm SAEW and UVC LED irradiation with 275 nm (100 SAEW + UVC LED). a-e; A-C; f-h Different letters within each treatment represent significant differences by Duncan's multiple tests at $p<0.05$. 

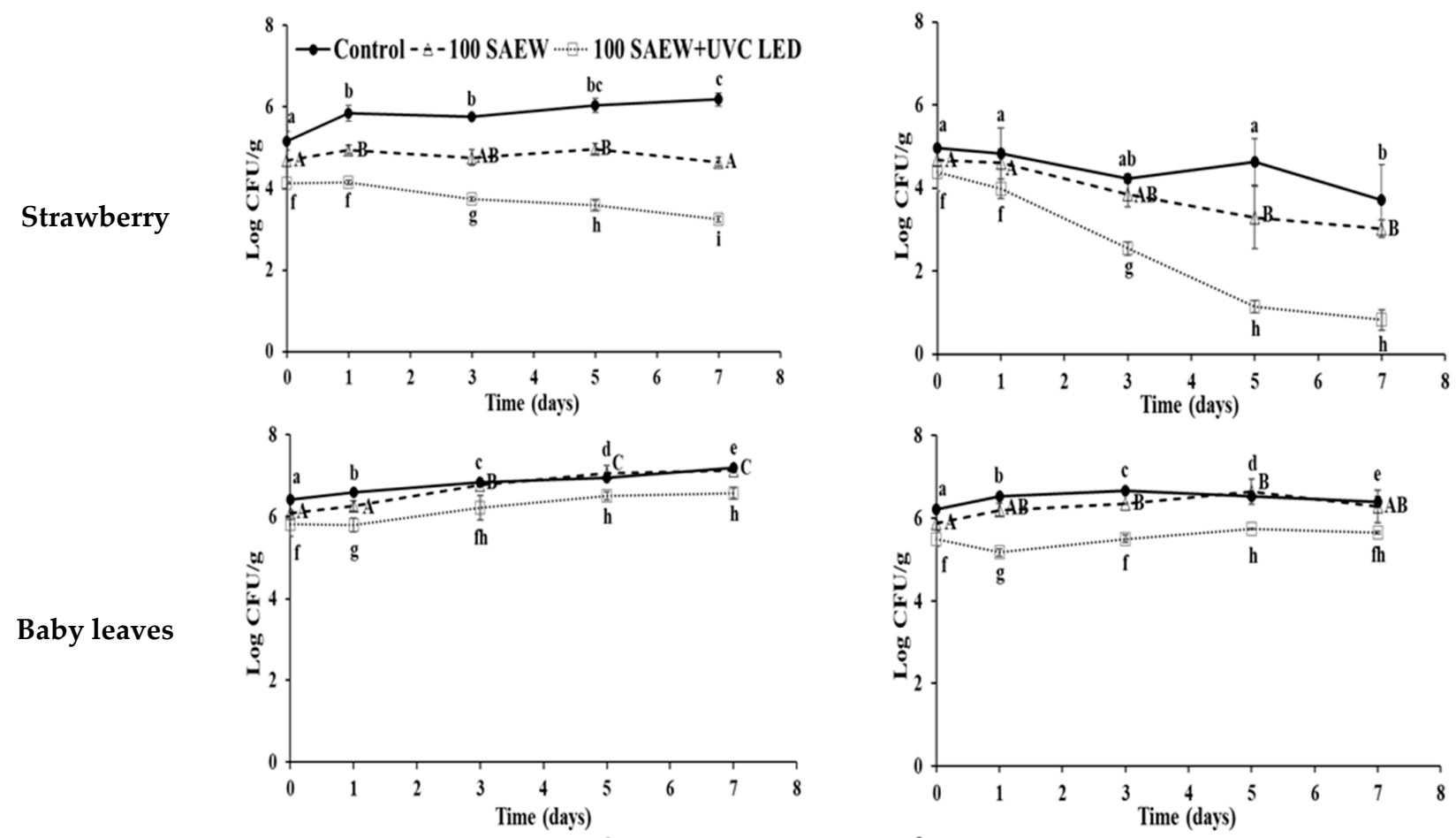

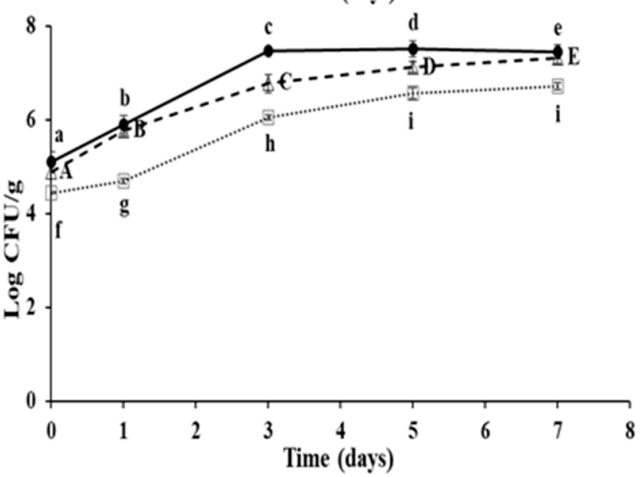

(a)

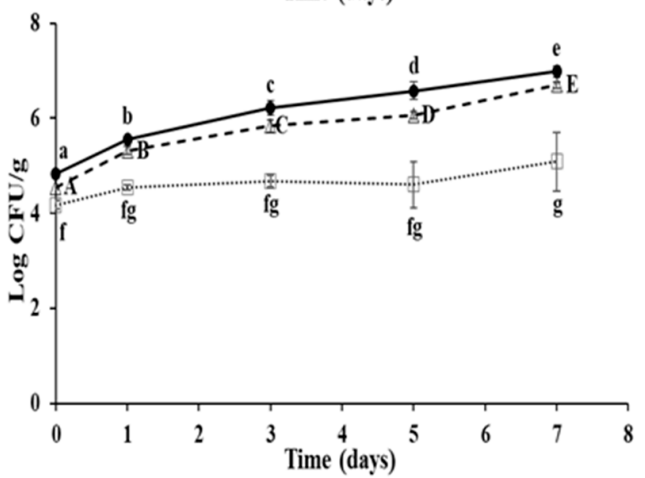

(b)

Figure 3. Log number of enterohemorrhagic E. coli (EHEC) (a) and S. aureus (b) after treatment in strawberry, baby leaves, and sliced onion stored for 7 days at $15^{\circ} \mathrm{C}$. $\bullet$, no extra wash with sanitizer (control); $\triangle$, aerosolization with 100 ppm SAEW (100 SAEW); $\square$, aerosolization with 100 ppm SAEW and UVC LED irradiation with $275 \mathrm{~nm}$ (100 SAEW + UVC LED). a-e; A-E; f-i Different letters within each treatment represent significant differences by Duncan's multiple tests at $p<0.05$.

At $10{ }^{\circ} \mathrm{C}$, the population of EHEC in the strawberry control group and 100 SAEW group was maintained, whereas the population of EHEC decreased by $0.8 \log \mathrm{CFU} \mathrm{g}^{-1}$ in strawberries treated with 100 SAEW and UVC LED during the 7 days of storage (Figure 2a). On the other hand, the growth of EHEC in baby leaves was not inhibited in any of the treatment conditions. For sliced onions, the control group, $100 \mathrm{SAEW}$ group, and combined group with 100 SAEW and UVC LED maintained the populations of EHEC for 5 days of storage. The control group and the 100 SAEW group showed increases of $0.87-1.3 \operatorname{log~CFU~g~}^{-1}$ on the EHEC population after 5 days of storage, whereas the combined treatment group inhibited the growth of EHEC and decreased its population at this point of storage.

At $10^{\circ} \mathrm{C}$, the population of $S$. aureus in strawberries showed decreases in all treatment conditions (Figure $2 \mathrm{~b}$ ). The population of $S$. aureus in strawberries showed a more rapid reduction with combined treatment of 100 SAEW and UVC LED than control or 100 SAEW treatment. The combined treatment reduced $S$. aureus population in strawberries the most (by $2.7 \log \mathrm{CFU} \mathrm{g}^{-1}$ ) after 7 days of storage, followed by 100 SAEW (1.82 log CFU g ${ }^{-1}$ ) and control $\left(1.3 \log \mathrm{CFU} \mathrm{g}^{-1}\right)$. The groups of $100 \mathrm{SAEW}$ and combined treatment of $100 \mathrm{SAEW}$ 
and UVC LED inhibited the growth of S. aureus in baby leaves and sliced onion during storage. However, increased growth of $S$. aureus (about $0.77 \log \mathrm{CFU} \mathrm{g}{ }^{-1}$ ) in sliced onion was observed in the control group.

At $15{ }^{\circ} \mathrm{C}$, the growth of EHEC in strawberries was prevented with 100 SAEW and combined treatment of 100 SAEW and UVC LED, whereas a $1.0 \log _{\text {CFU g }}{ }^{-1}$ increase in EHEC in strawberries was observed in the control group after 7 days of storage (Figure 3a). However, the growth of EHEC in baby leaves and sliced onions was not inhibited in any of the treatment conditions.

On the other hand, populations of S. aureus in strawberries were decreased after 7 days of storage in all treatment conditions (Figure 3b). The combined treatment of 100 SAEW and UVC LED resulted in the most significant reduction in $S$. aureus population in strawberries (3.57 $\log$ CFU g $\left.{ }^{-1}\right)$, followed by 100 SAEW (1.64 $\log$ CFU g ${ }^{-1}$ ) and control (1.26 log CFU $\left.\mathrm{g}^{-1}\right)$. Growth of $S$. aureus in baby leaves and sliced onions was observed in all treatment conditions. However, $S$. aureus in both baby leaves and sliced onions showed the least growth with 100 SAEW and UVC LED treatment. These results indicate that the combined treatment could be an effective tool to extend shelf life for soft fresh produce and meal kit vegetables such as sliced onions.

Several previous studies have reported different behaviors of foodborne pathogens in fresh produce during storage after a reduction treatment [17,28,29,31,40-42]. Growths of E. coli and S. aureus in carrots and celery have been observed after treatment with a combination of 30 ppm SAEW, ultrasound, and UVC LED when they are stored at $15^{\circ} \mathrm{C}$ for 7 days [28]. Likewise, Jiang et al. [29] reported the growth of both Salmonella spp. and E. coli O157:H7 in coriander during 6 days of storage at $4{ }^{\circ} \mathrm{C}$ after combined treatment of 60 ppm SAEW and UVC LED irradiation. Populations of total aerobic bacteria (TAB) and yeast and mold (YM) in lettuce and kale are also increased after combined treatment of 50 ppm $\mathrm{ClO}_{2}$ and UVC irradiation after 7 days of storage at $4{ }^{\circ} \mathrm{C}$ [39]. However, the growth of Salmonella spp. in cherry tomatoes was inhibited by aerosolization with water, 200 ppm chlorine, peroxyacetic acid $(80 \sim 400 \mathrm{ppm})$, or aqueous $\mathrm{ClO}_{2}(3 \sim 400 \mathrm{ppm})$ during 3 weeks of storage at $10^{\circ} \mathrm{C}$ [17].

TAB decreased for Fuji apples washed with 50 ppm acidic electrolyzed water during 35 days of storage at $10{ }^{\circ} \mathrm{C}$ [43]. Massey et al. [44] also reported that electrostatic spray of $2 \%$ malic acid and $2 \%$ lactic acid could decrease the E. coli O157:H7 population in cantaloupe cubes by $1.9 \log \mathrm{CFU} \mathrm{g}{ }^{-1}$ after 12 days of storage at $4{ }^{\circ} \mathrm{C}$. Combined treatment of aerosolization with $2 \%$ malic acid and UVC irradiation could reduce the populations of E. coli O157:H7, Salmonella Typhimurium, and Listeria monocytogenes in fresh-cut lettuces after 15 days of storage at $5{ }^{\circ} \mathrm{C}$ [31].

In the present study, EHEC and $S$. aureus populations in strawberries were decreased by the combined treatment during storage at 10 and $15^{\circ} \mathrm{C}$, whereas the growth of both EHEC and S. aureus was not inhibited in baby leaves and sliced onions, and the populations of both pathogens were maintained. The behaviors of pathogens could vary depending on the activity of water $\left(\mathrm{a}_{\mathrm{w}}\right)$ or the $\mathrm{pH}$ of the food, even within the same type of ready-to-eat food [45]. Such differences in EHEC and S. aureus growth among tested groups appeared to be due to the different $\mathrm{pHs}$ of soft fresh produce tested in this work. Strawberries $(3.36 \pm 0.03)$ have lower $\mathrm{pH}$ than baby leaves $(6.49 \pm 0.02)$ and sliced onion $(5.81 \pm 0.20)$. Thus, the proper and effective tool should be applied by considering the characteristics of each food to promote the safety of fresh produce at the market.

3.3. Effect of Combined Treatment of Aerosolization and UVC LED Irradiation on Moisture Loss of Soft Fresh Produce during Storage at 10 and $15^{\circ} \mathrm{C}$

Overall, significantly lower moisture losses were observed at $10{ }^{\circ} \mathrm{C}(3.50 \pm 0.19 \%)$ than at $15{ }^{\circ} \mathrm{C}(5.38 \pm 0.61 \%)$ in all samples. The average moisture loss in strawberries, baby leaves, and sliced onion was $2.47 \%, 3.87 \%$, and $4.16 \%$ at $10{ }^{\circ} \mathrm{C}$, respectively, and $5.91 \%, 4.57 \%$, and $5.65 \%$ at $15{ }^{\circ} \mathrm{C}$, respectively (Figure 4 ). At $10{ }^{\circ} \mathrm{C}$, the moisture loss of strawberries in the $100 \mathrm{SAEW}$ and UVC LED group was not significantly different from that in the control treatment group (Figure $4 \mathrm{a}$ ). At $15^{\circ} \mathrm{C}$, higher moisture loss was observed 
for the control group $(8.10 \pm 2.70 \%)$ than for the 100 SAEW and UVC LED $(3.94 \pm 0.09 \%)$, as shown in Figure $4 \mathrm{~b}$. On the other hand, significantly higher moisture loss was observed in baby leaves treated with the combined treatment at 10 and $15{ }^{\circ} \mathrm{C}$. In sliced onions, significantly higher moisture loss was only observed with the combined treatment at $15^{\circ} \mathrm{C}$. These results indicate that the combined treatment increased the moisture loss in baby leaves and sliced onions at 10 and $15{ }^{\circ} \mathrm{C}$.

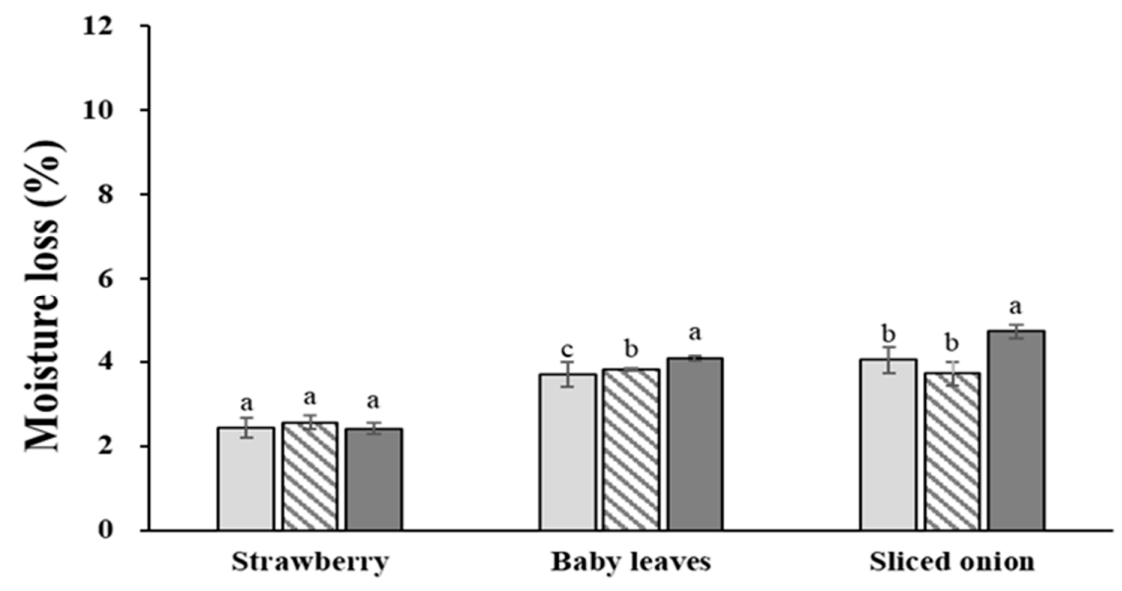

(a)

\section{$\square$ Control $\triangle 100$ SAEW $\square 100$ SAEW+UVC LED}

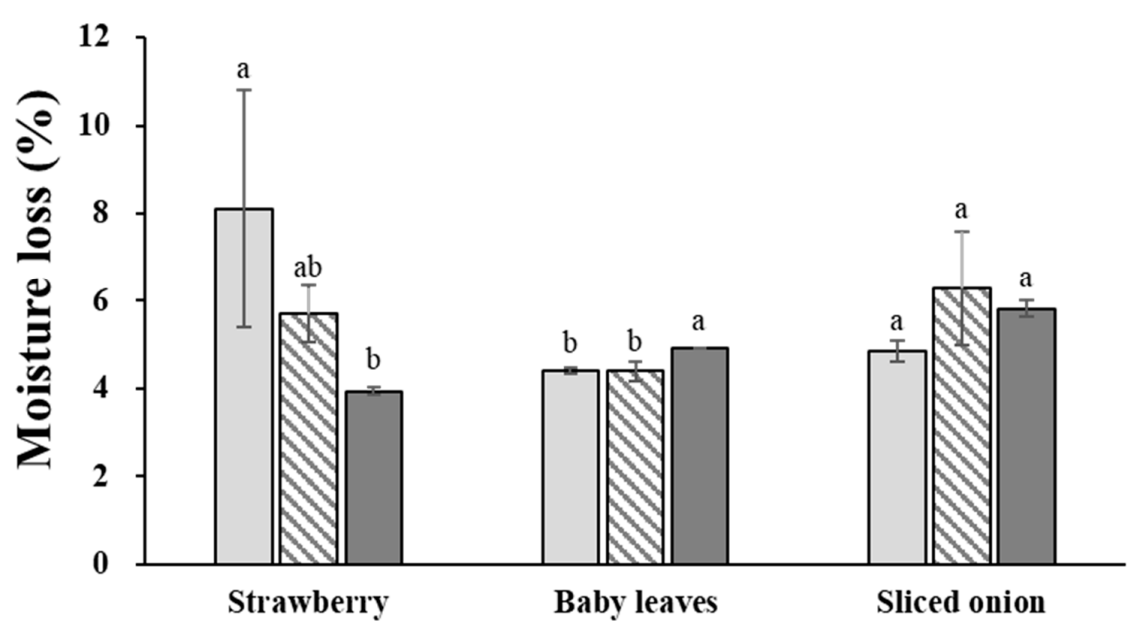

(b)

Figure 4. Moisture loss of strawberry, baby leaves, and sliced onion during storage at (a) 10 and (b) $15{ }^{\circ} \mathrm{C}$ for 7 days after applying to inactivate treatment. Control, no extra wash with a sanitizer; 100 SAEW, aerosolization with 100 ppm SAEW; 100 SAEW + UVC LED, aerosolization with 100 ppm SAEW and UVC LED radiation $(275 \mathrm{~nm})$. ${ }^{\mathrm{a}-\mathrm{c}}$ Different letters represent significant differences measured by Duncan's multiple tests among treatments within each soft fresh produce at $p<0.05$.

Moisture loss is a major factor related to colour changes of stored strawberries. Moisture loss releases polyphenol oxidase (PPO) enzyme and lowers the concentration of anthocyanin. Thus, moisture loss plays an important role in anthocyanin degradation [46]. Therefore, several studies have investigated precooling, modified atmosphere packaging, and edible coating technologies to prevent moisture loss of strawberries, thus extending their shelf life [47-49]. Strawberries with an edible coating (2-3\% soy protein-based or $2-3 \%$ alginate-based coating) show moisture loss of $4.41 \%$ on the 7 th day of storage at $4{ }^{\circ} \mathrm{C}$ [49]. In the present study, strawberries treated with the combined treatment showed significantly lower moisture losses of $2.42 \pm 0.14 \%$ and $3.94 \pm 0.09 \%$ at the 7 th day of 
storage at 10 and $15^{\circ} \mathrm{C}$, respectively. These results indicate that the combined treatment of 100 SAEW and UVC LED could effectively prevent quality changes during cold storage, especially in strawberries.

3.4. Effect of Combined Treatment of Aerosolization and UVC LED on Visual Appearance Evolution and Colour Measurement of Soft Fresh Produce during Storage at 10 and $15^{\circ} \mathrm{C}$

Strawberries treated with the combined treatment showed a better evolution of visual appearance than those that were untreated (controls) or treated with 100 SAEW after 7 days of storage at 10 and $15{ }^{\circ} \mathrm{C}$ (Figure 5). At $10{ }^{\circ} \mathrm{C}$, the strawberries from the control group started to show browning on the 4 th day of storage, and mold appeared from the 5 th day of storage. For strawberries treated with 100 SAEW, mold was also detected from the 5th day of storage. However, strawberries treated with combined treatment showed no mold or browning until the 7 th day of storage (Figure 5a). The $a^{*}$ value of strawberries treated with combined treatment on the 4 th day was not significantly different from control on day 0 (Table 1 ).

At $15{ }^{\circ} \mathrm{C}$, mold was observed from the 2 nd day of storage. Spoilage of strawberries in the control group progressed from the 4 th day of storage. Strawberries from 100 SAEW group showed browning on the surface from the 4th day of storage. In the combined treatment of 100 SAEW and UVC LED group, surface browning of strawberries was noticed from the 6th day of storage. However, mold was not confirmed until the 7 th day of storage (Figure $5 \mathrm{~b}$ ). The $a^{*}$ value of strawberries treated with combined treatment on the 4th day was not significantly different from those from the control or treated with SAEW 100 group during 0 day of storage. Furthermore, the $a^{*}$ value of strawberries treated with combined treatment on the 7th day was significantly higher than those from the control or 100 SAEW groups on 4th day (Table 2).

Baby leaves treated with combined treatment were confirmed to show a better visual appearance than those from the control group or 100 SAEW group during storage at 10 and $15^{\circ} \mathrm{C}$ (Figure 6). At $10{ }^{\circ} \mathrm{C}$, leaf discoloration was noticeable for baby leaves in the control group during storage from the 3rd day of storage. In the 100 SAEW group, leaf discoloration began to be observed from the 5 th day of storage, whereas the visual appearance of baby leaves in the combined treatment group did not change over 7 days (Figure 6a). At $15^{\circ} \mathrm{C}$, leaf discoloration was noticed for baby leaves after 2-3 days of storage in the control group and the 100 SAEW group. Discolored leaves started to decay and give a foul odor from 4 days of storage. However, baby leaves treated with combined treatment only showed leaf discoloration on the last day of storage (Figure 6b).

The $L^{*}$ and $b^{*}$ values of baby leaves in the control group and 100 SAEW group were increased during storage at 10 and $15^{\circ} \mathrm{C}$ (Tables 1 and 2). As yellowish baby leaves occurred in the control and the 100 SAEW groups, these leaves became brighter, indicating an increase in $L^{*}$ and $b^{*}$ values. However, $L^{*}$ and $b^{*}$ values of baby leaves in the combined treatment group were not significantly different from each other at the 4 th or 7 th day of storage at 10 or $15{ }^{\circ} \mathrm{C}$ because leaf discoloration did not occur in this group. However, the $b^{*}$ value of sliced onion treated with combined treatment was significantly different from the control group and 100 SAEW group on the 4 th and 7 th day of storage at $10{ }^{\circ} \mathrm{C}$ (Table 1 ) and on the 7 th day of storage at $15{ }^{\circ} \mathrm{C}$ (Table 2 ). We observed that each treatment affected the color and appearance of sliced onions, and the visual appearance of sliced onions treated with combined treatment was better on the 7 th day of storage compared to the other two treatment groups (Figure $7 \mathrm{a}$ ). At $15{ }^{\circ} \mathrm{C}$, the browning of sliced onions started from day 5 in all treatment conditions, but less damage and decay were observed in the combined treatment group during storage compared to the control group and 100 SAEW group (Figure $7 \mathrm{~b}$ ). The $b^{*}$ value of sliced onions constantly increased during storage at both temperatures in all treatment groups (Tables 1 and 2). A significant difference in the $b^{*}$ values was noticed among treatments with increased storage time (Table 1 ). 

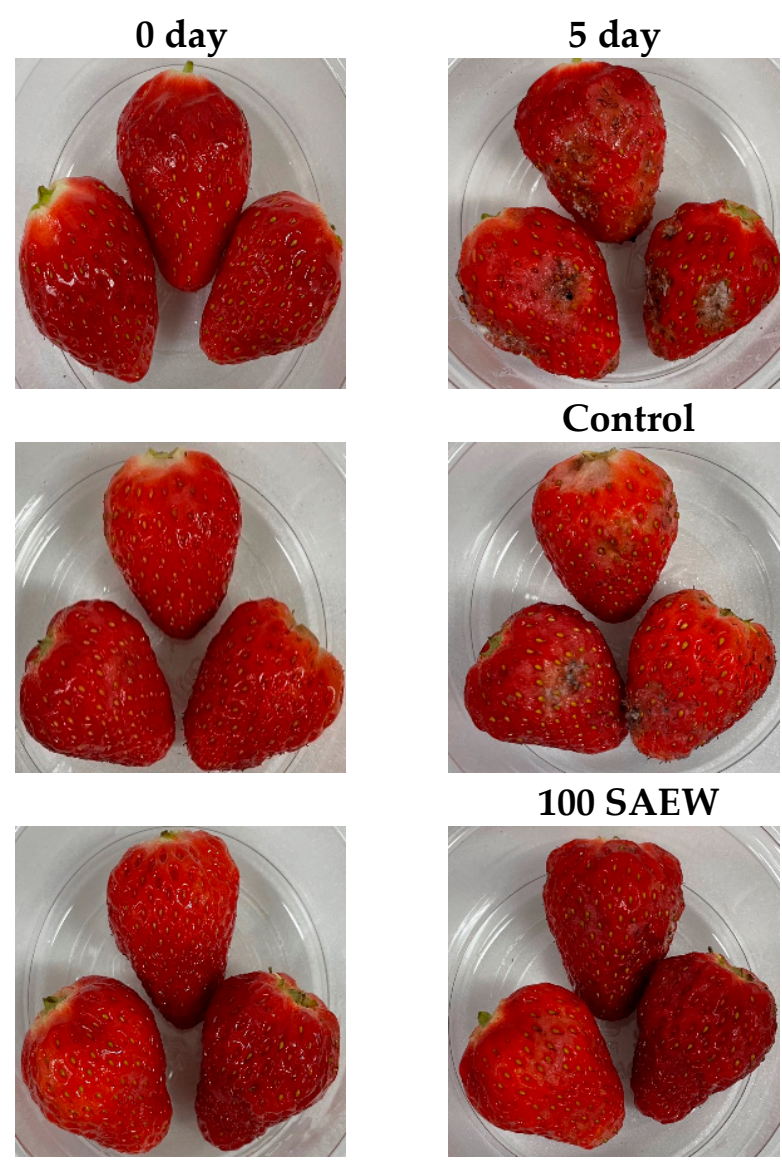

Control

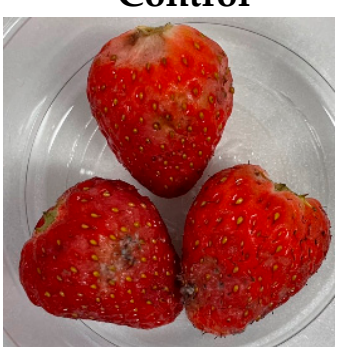

100 SAEW

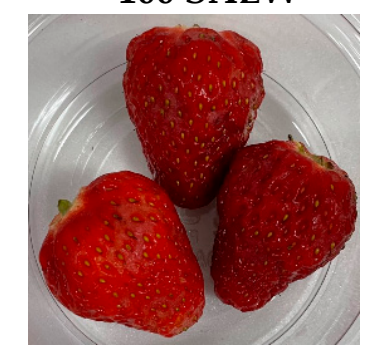

100 SAEW + UVC LED

(a)
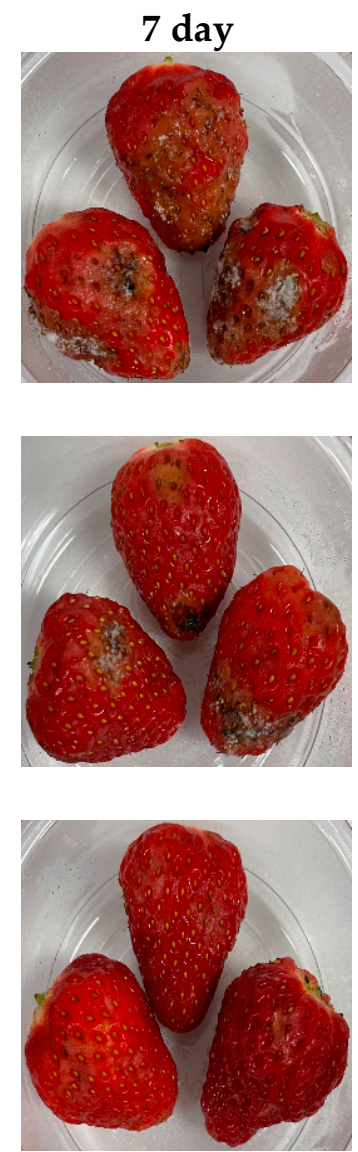

)
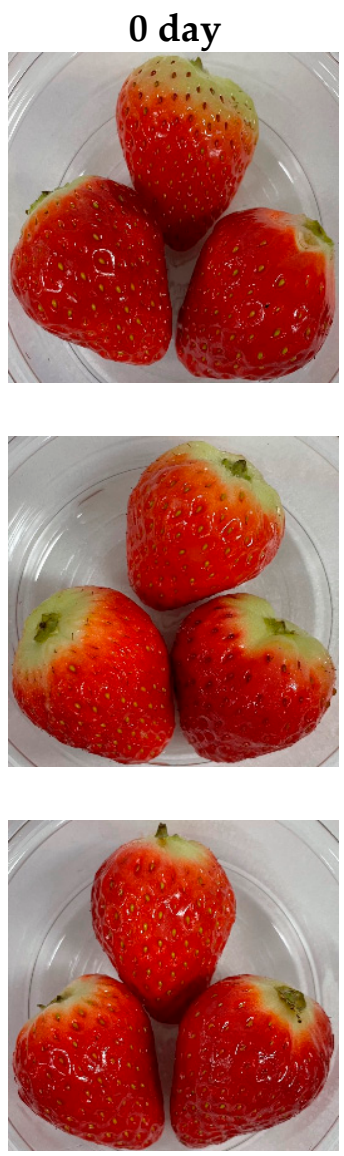

100 SAEW + UVC LED

(b)

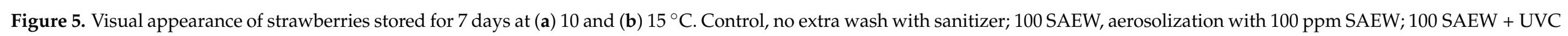
LED, aerosolization with $100 \mathrm{ppm}$ SAEW and UVC LED irradiation $(275 \mathrm{~nm})$ for $3 \mathrm{~min}$. 
Table 1. Effect of combined treatment on $L^{*}, a^{*}, b^{*}$ values in soft fresh produce during 7 days of storage at $10^{\circ} \mathrm{C}$.

\begin{tabular}{|c|c|c|c|c|c|c|c|c|c|c|}
\hline \multirow{2}{*}{ Treatments } & \multirow{2}{*}{ Storage Time } & \multicolumn{3}{|c|}{ Strawberry } & \multicolumn{3}{|c|}{ Baby Leaves } & \multicolumn{3}{|c|}{ Sliced Onion } \\
\hline & & $L^{*}$ & $a^{*}$ & $b^{*}$ & $L^{*}$ & $a^{*}$ & $b^{*}$ & $L^{*}$ & $a^{*}$ & $b^{*}$ \\
\hline \multirow{3}{*}{ Control } & $0 \mathrm{~d}$ & $33.90 \pm 0.86^{a}$ & $35.17 \pm 0.88^{\mathrm{ab}}$ & $15.68 \pm 0.54^{\mathrm{a}}$ & $35.26 \pm 1.19^{c}$ & $-9.96 \pm 0.46^{\mathrm{a}}$ & $11.18 \pm 0.14^{\mathrm{e}}$ & $63.00 \pm 1.14^{\mathrm{a}}$ & $-1.07 \pm 0.12^{a}$ & $3.26 \pm 0.05^{\mathrm{d}}$ \\
\hline & $4 \mathrm{~d}$ & $34.59 \pm 1.57^{\mathrm{a}}$ & $24.36 \pm 1.23^{c}$ & $13.11 \pm 1.39 b c$ & $43.07 \pm 4.01^{b}$ & $-10.18 \pm 0.15^{a}$ & $15.28 \pm 0.80^{b}$ & $62.85 \pm 0.91^{\mathrm{a}}$ & $-1.12 \pm 0.13^{a}$ & $6.25 \pm 0.30^{b}$ \\
\hline & $7 \mathrm{~d}$ & $33.84 \pm 1.06^{\mathrm{a}}$ & $9.71 \pm 0.77^{\mathrm{d}}$ & $11.20 \pm 0.20^{\mathrm{d}}$ & $62.74 \pm 3.33^{a}$ & $-9.96 \pm 0.54^{\mathrm{a}}$ & $28.87 \pm 0.13^{a}$ & $62.70 \pm 0.62^{\mathrm{a}}$ & $-1.14 \pm 0.02^{\mathrm{a}}$ & $8.74 \pm 0.18^{a}$ \\
\hline \multirow{3}{*}{100 SAEW } & $0 \mathrm{~d}$ & $34.68 \pm 0.84^{\mathrm{a}}$ & $35.57 \pm 0.47^{\mathrm{a}}$ & $16.10 \pm 0.38^{a}$ & $34.28 \pm 2.18^{c}$ & $-10.07 \pm 0.57^{a}$ & $11.79 \pm 0.59 \mathrm{de}$ & $62.01 \pm 0.40^{\mathrm{ab}}$ & $-1.05 \pm 0.10^{\mathrm{a}}$ & $3.36 \pm 0.33^{d}$ \\
\hline & $4 \mathrm{~d}$ & $35.06 \pm 0.79^{a}$ & $23.05 \pm 4.39^{c}$ & $13.63 \pm 0.79^{b}$ & $35.60 \pm 3.56^{c}$ & $-9.97 \pm 0.34^{\mathrm{a}}$ & $14.79 \pm 0.89^{b}$ & $62.31 \pm 0.84^{\mathrm{a}}$ & $-1.14 \pm 0.06^{\mathrm{a}}$ & $6.34 \pm 0.37^{b}$ \\
\hline & $7 \mathrm{~d}$ & $35.07 \pm 0.90^{\mathrm{a}}$ & $9.54 \pm 0.90^{\mathrm{d}}$ & $11.76 \pm 0.27^{\mathrm{d}}$ & $59.07 \pm 1.31^{\mathrm{a}}$ & $-10.52 \pm 0.47^{a}$ & $28.13 \pm 1.43^{\mathrm{a}}$ & $61.97 \pm 0.54^{\mathrm{ab}}$ & $-1.16 \pm 0.16^{\mathrm{a}}$ & $8.66 \pm 0.89^{a}$ \\
\hline \multirow{3}{*}{$\begin{array}{r}100 \text { SAEW } \\
+ \text { UVC LED }\end{array}$} & $0 \mathrm{~d}$ & $34.57 \pm 0.92^{\mathrm{a}}$ & $35.33 \pm 0.63^{a}$ & $15.92 \pm 0.72^{\mathrm{a}}$ & $34.10 \pm 0.23^{c}$ & $-10.24 \pm 0.36^{a}$ & $11.08 \pm 0.68^{\mathrm{e}}$ & $61.25 \pm 1.29 \mathrm{ab}$ & $-1.06 \pm 0.12^{\mathrm{a}}$ & $3.50 \pm 0.20^{\mathrm{d}}$ \\
\hline & $4 \mathrm{~d}$ & $34.11 \pm 0.39^{a}$ & $34.17 \pm 0.60 \mathrm{ab}$ & $13.07 \pm 0.37 \mathrm{bc}$ & $36.94 \pm 0.84^{c}$ & $-9.96 \pm 0.22^{\mathrm{a}}$ & $12.94 \pm 0.35^{\mathrm{cd}}$ & $61.72 \pm 1.42^{\mathrm{ab}}$ & $-1.09 \pm 0.13^{\mathrm{a}}$ & $4.94 \pm 0.53^{c}$ \\
\hline & $7 \mathrm{~d}$ & $34.33 \pm 0.79^{a}$ & $31.53 \pm 1.10^{b}$ & $11.76 \pm 0.27^{\mathrm{cd}}$ & $35.99 \pm 1.74^{c}$ & $-9.53 \pm 0.50^{a}$ & $13.64 \pm 0.89 \mathrm{bc}$ & $60.14 \pm 0.51^{\mathrm{b}}$ & $-1.24 \pm 0.06^{\mathrm{a}}$ & $6.12 \pm 0.35^{b}$ \\
\hline
\end{tabular}

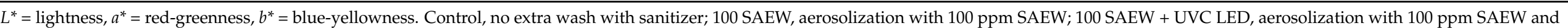

UVC LED irradiation $(275 \mathrm{~nm})$ for $3 \mathrm{~min}$. ${ }^{\mathrm{a}-\mathrm{e}}$ Different letters in the same column indicate significant differences measured by Duncan's multiple tests at $(p<0.05)$.

Table 2. Effect of combined treatment on $L^{*}, a^{*}, b^{*}$ values in soft fresh produce during 7 days of storage at $15^{\circ} \mathrm{C}$.

\begin{tabular}{|c|c|c|c|c|c|c|c|c|c|c|}
\hline \multirow{2}{*}{ Treatments } & \multirow{2}{*}{ Storage Time } & \multicolumn{3}{|c|}{ Strawberry } & \multicolumn{3}{|c|}{ Baby Leaves } & \multicolumn{3}{|c|}{ Sliced Onion } \\
\hline & & $L^{*}$ & $a^{*}$ & $b^{*}$ & $L^{*}$ & $a^{*}$ & $b^{*}$ & $L^{*}$ & $a^{*}$ & $b^{*}$ \\
\hline \multirow{3}{*}{ Control } & $0 \mathrm{~d}$ & $34.57 \pm 0.83^{a}$ & $34.85 \pm 0.71^{a}$ & $16.13 \pm 0.63^{a}$ & $35.62 \pm 3.23^{d}$ & $-9.98 \pm 0.38^{a}$ & $11.67 \pm 1.04^{\mathrm{d}}$ & $60.83 \pm 1.08^{a}$ & $-1.04 \pm 0.12^{a}$ & $3.35 \pm 0.17^{c}$ \\
\hline & $4 \mathrm{~d}$ & $34.82 \pm 0.60^{a}$ & $16.05 \pm 1.82^{c}$ & $14.07 \pm 0.50^{b}$ & $51.95 \pm 0.48^{b}$ & $-10.06 \pm 1.02^{a}$ & $24.35 \pm 1.68^{b}$ & $60.71 \pm 1.14^{\mathrm{a}}$ & $-1.19 \pm 0.24^{\mathrm{a}}$ & $7.79 \pm 0.29^{b}$ \\
\hline & $7 \mathrm{~d}$ & $35.22 \pm 0.19^{a}$ & $9.40 \pm 0.85^{\mathrm{d}}$ & $10.99 \pm 0.64^{c}$ & $63.91 \pm 1.26^{\mathrm{a}}$ & $-10.48 \pm 0.68^{a}$ & $31.85 \pm 1.33^{\mathrm{a}}$ & $61.42 \pm 1.66^{\mathrm{a}}$ & $-1.06 \pm 0.08^{a}$ & $12.07 \pm 1.65^{\mathrm{a}}$ \\
\hline \multirow{3}{*}{100 SAEW } & $0 \mathrm{~d}$ & $34.43 \pm 0.63^{a}$ & $35.16 \pm 0.41^{a}$ & $16.39 \pm 0.86^{a}$ & $35.19 \pm 1.91^{\mathrm{d}}$ & $-9.86 \pm 0.29^{a}$ & $11.24 \pm 0.73^{\mathrm{d}}$ & $61.95 \pm 1.46^{\mathrm{a}}$ & $-1.06 \pm 0.17^{a}$ & $3.33 \pm 0.11^{c}$ \\
\hline & $4 \mathrm{~d}$ & $34.60 \pm 0.86^{a}$ & $18.72 \pm 2.05^{c}$ & $14.08 \pm 0.28^{b}$ & $46.15 \pm 0.80^{c}$ & $-10.43 \pm 0.50^{a}$ & $15.84 \pm 0.55^{\mathrm{c}}$ & $61.14 \pm 0.85^{\mathrm{a}}$ & $-1.14 \pm 0.07^{\mathrm{a}}$ & $7.65 \pm 0.48^{b}$ \\
\hline & $7 \mathrm{~d}$ & $34.90 \pm 0.42^{\mathrm{a}}$ & $10.33 \pm 0.89^{d}$ & $10.60 \pm 0.67^{c}$ & $61.12 \pm 0.39^{a}$ & $-9.63 \pm 0.48^{a}$ & $26.05 \pm 1.81^{b}$ & $62.48 \pm 1.45^{\mathrm{a}}$ & $-1.03 \pm 0.09^{a}$ & $11.41 \pm 0.88^{a}$ \\
\hline \multirow{3}{*}{$\begin{array}{r}100 \text { SAEW } \\
+ \text { UVC LED }\end{array}$} & $0 \mathrm{~d}$ & $34.71 \pm 0.25^{\mathrm{a}}$ & $34.79 \pm 0.41^{\mathrm{a}}$ & $16.25 \pm 0.25^{a}$ & $34.01 \pm 0.37^{\mathrm{d}}$ & $-9.56 \pm 0.21^{\mathrm{a}}$ & $11.26 \pm 0.87^{\mathrm{d}}$ & $61.31 \pm 0.61^{\mathrm{a}}$ & $-1.13 \pm 0.07^{\mathrm{a}}$ & $3.45 \pm 0.13^{c}$ \\
\hline & $4 \mathrm{~d}$ & $34.77 \pm 0.83^{a}$ & $34.42 \pm 0.62^{\mathrm{a}}$ & $13.94 \pm 0.31^{b}$ & $34.46 \pm 1.43^{\mathrm{d}}$ & $-9.96 \pm 0.54^{\mathrm{a}}$ & $14.31 \pm 0.56^{\mathrm{c}}$ & $62.26 \pm 2.71^{a}$ & $-1.18 \pm 0.14^{a}$ & $6.67 \pm 0.18^{b}$ \\
\hline & $7 \mathrm{~d}$ & $34.86 \pm 0.11^{a}$ & $30.59 \pm 2.68^{b}$ & $11.33 \pm 0.35^{c}$ & $35.21 \pm 0.63^{d}$ & $-10.08 \pm 0.39^{a}$ & $15.19 \pm 0.43^{c}$ & $61.56 \pm 0.75^{\mathrm{a}}$ & $-1.14 \pm 0.08^{a}$ & $7.27 \pm 0.29^{b}$ \\
\hline
\end{tabular}

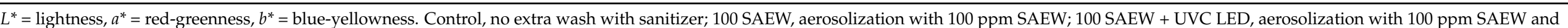

UVC LED irradiation $(275 \mathrm{~nm})$ for $3 \mathrm{~min}$. ${ }^{a-e}$ Different letters in the same column indicate significant differences measured by Duncan's multiple tests at $(p<0.05)$. 

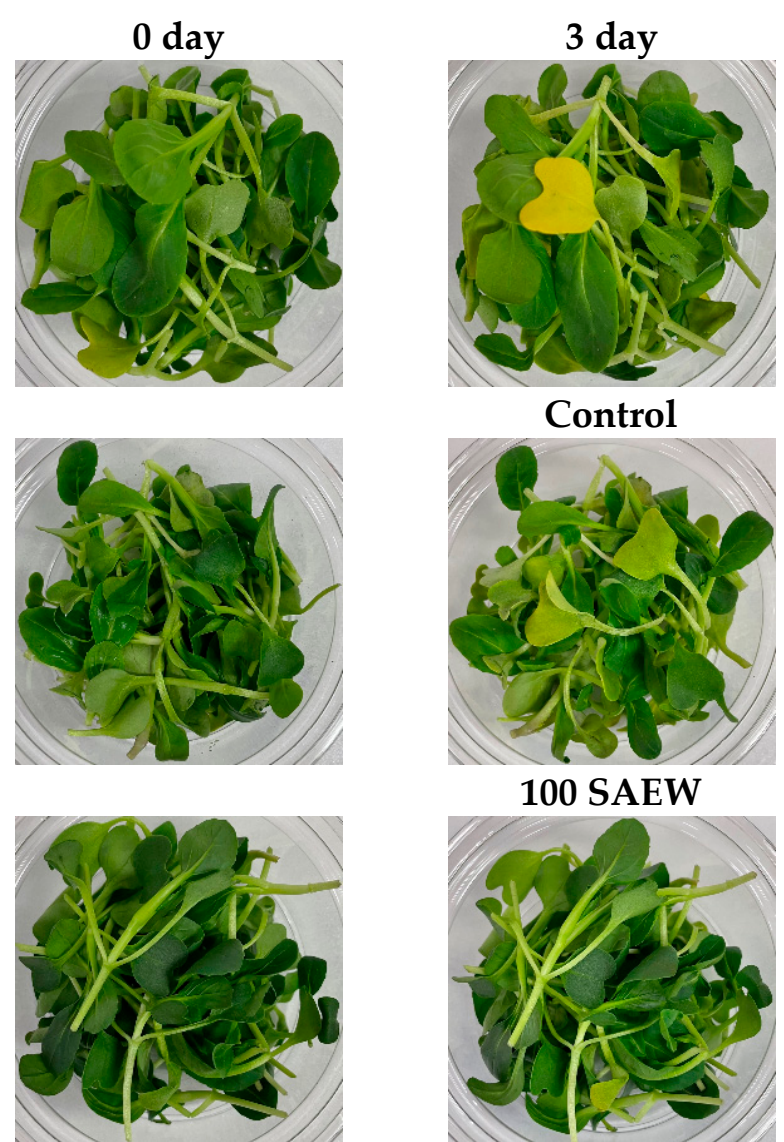

Control

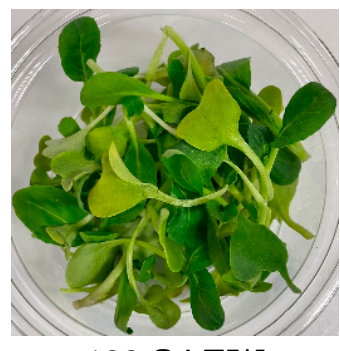

100 SAEW

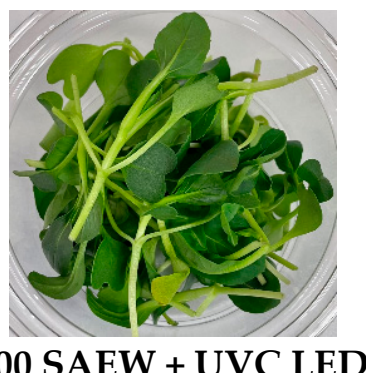

(a)

100 SAEW + UVC LED
7 day
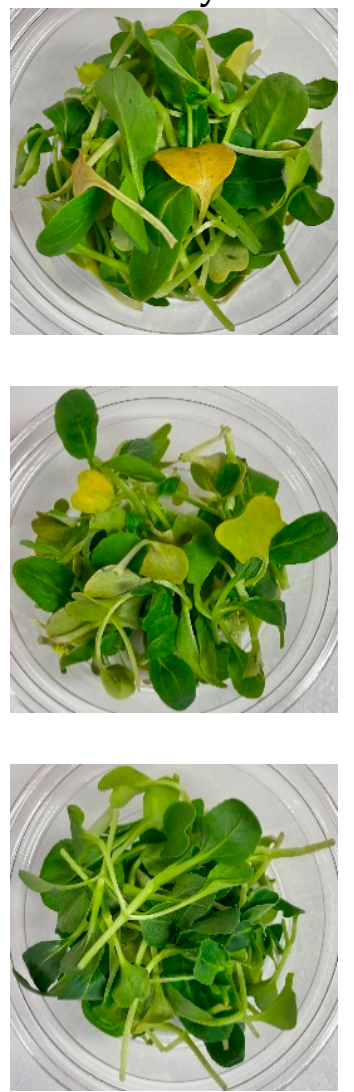
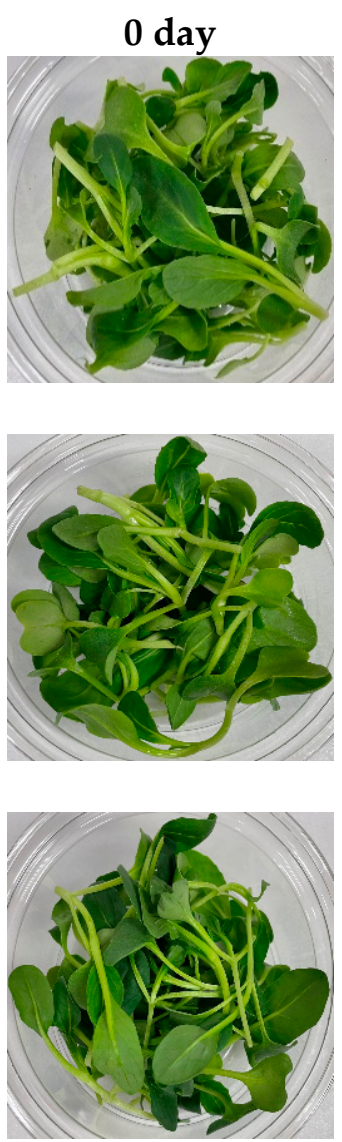

\section{SAEW + UVC LED}

(b)

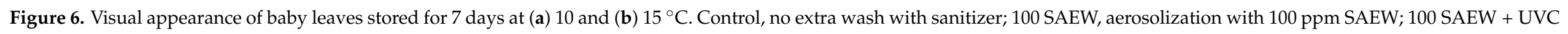
LED, aerosolization with 100 ppm SAEW and UVC LED irradiation $(275 \mathrm{~nm})$ for $3 \mathrm{~min}$. 

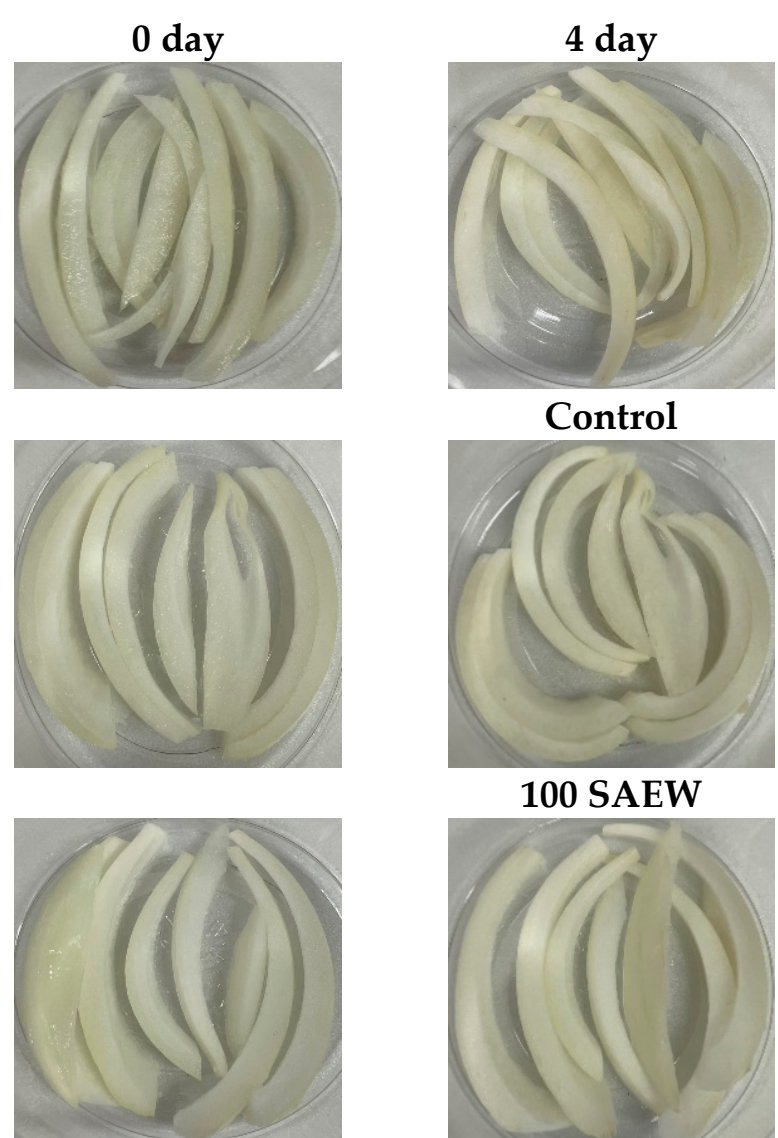

Control

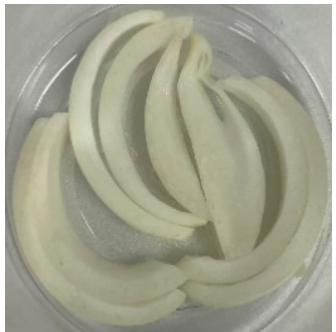

100 SAEW

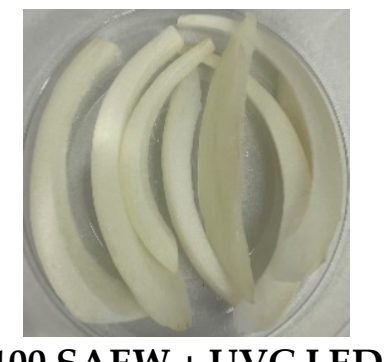

100 SAEW + UVC LED

(a)
7 day
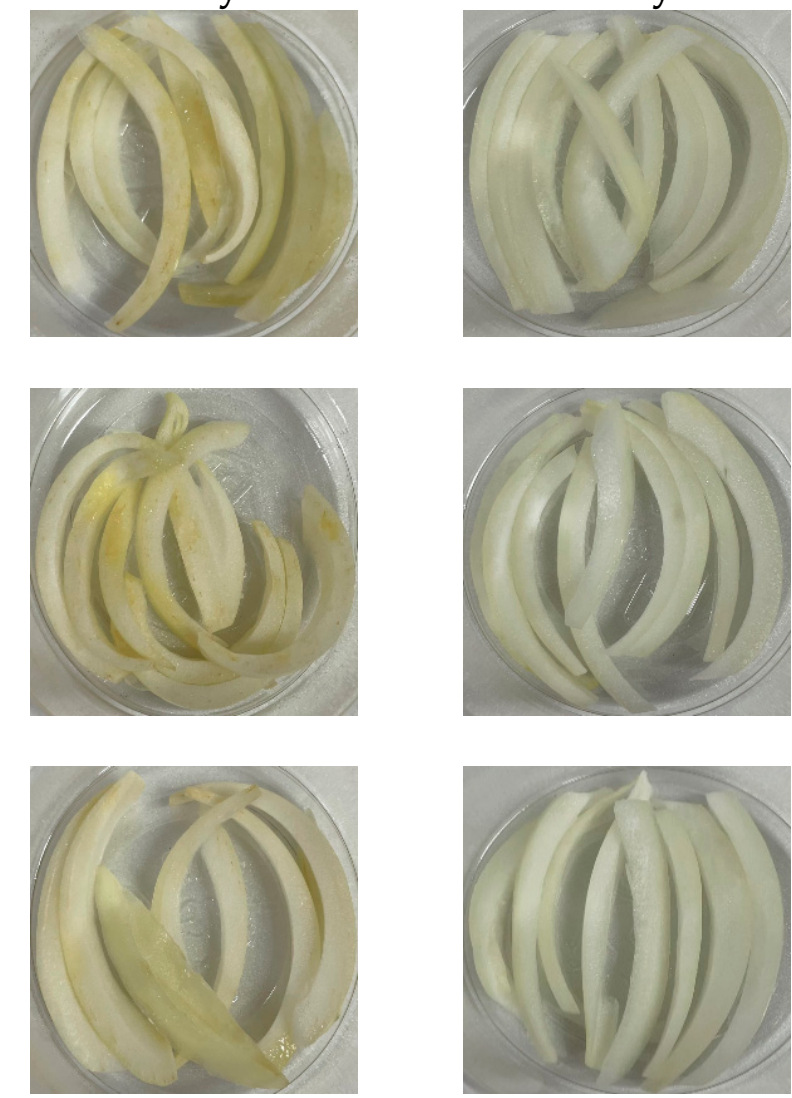
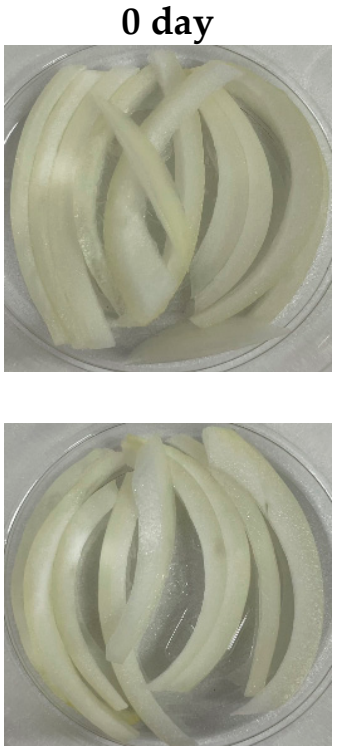

\section{,}

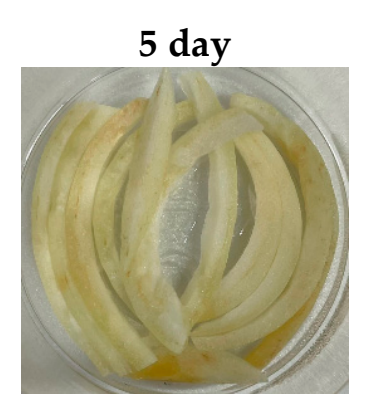

\section{Control}

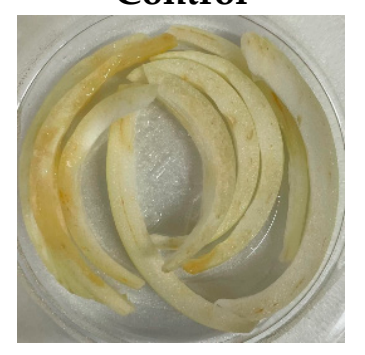

100 SAEW

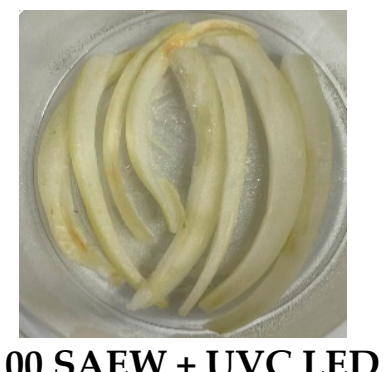

(b)
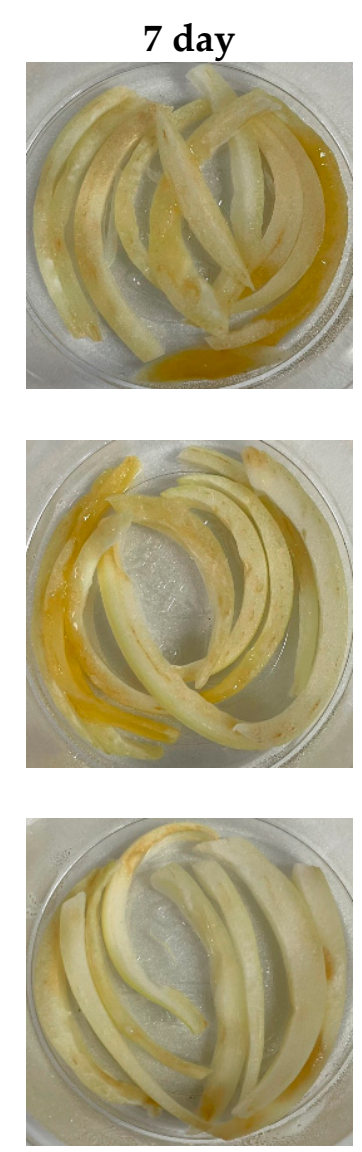

Figure 7. Visual appearance of sliced onions stored for 7 days at (a) 10 and $(\mathbf{b}) 15^{\circ} \mathrm{C}$. Control, no extra wash with sanitizer; $100 \mathrm{SAEW}$, aerosolization with $100 \mathrm{ppm}$ SAEW; $100 \mathrm{SAEW}+\mathrm{UVC}$ LED, aerosolization with $100 \mathrm{ppm}$ SAEW and UVC LED irradiation $(275 \mathrm{~nm})$ for $3 \mathrm{~min}$. 
UVC LED treatment $\left(500 \mathrm{~mJ} \mathrm{~cm}^{-2}\right.$ ) for apples inoculated with blue mold (Penicillium expansum) could prevent the development of blue mold and spoilage during 28 days of storage at $25^{\circ} \mathrm{C}$ [50]. UVC treatment could also reduce polyphenol oxidase (PPO) enzyme and improve tissue integrity of fresh-cut Carambola (Averrhoa carambola L.), also known as starfruit [40]. Reducing PPO could prevent moisture loss and decrease anthocyanin degradation, avoiding the surface browning in strawberries [46]. The present study also confirmed that strawberries treated with 100 SAEW and UVC LED show the least moisture losses and the greatest visual appearance evolution. The results of this study indicate that UVC treatment has the potential to extend the shelf life of soft fruits such as strawberries. UVC irradiation could also reduce enzyme activity associated with chlorophyll degradation catabolism. Chlorophyll degradation leads a green colour loss in leafy vegetables during chlorophyll degradation; chlorophyll is transformed to chlorophyllide by the chlorophyllase enzyme. Chlorophyllide is then progressed by the enzyme Mg-dechelatase, which removes $\mathrm{Mg}^{2+}$ from the chlorophyllide, forming pheophorbide. Consequently, the green colour is lost $[41,42,51]$. Activities of chlorophyllase and Mg-dechelatase in broccoli and Chinese kale decreased after irradiation with UVC, thus delaying leaf yellowing and showing higher chlorophyll content $[52,53]$. The results of the present study also show that baby leaves treated with combined treatment of 100 SAEW and UVC LED had less leaf discoloration and showed an improvement of visual appearance. Therefore, combined treatment of SAEW and UVC LED could extend their shelf life in baby leaves at the market by reducing microorganisms and preventing colour change.

\section{Conclusions}

In this study, the efficacy of single (60 SAEW, $100 \mathrm{SAEW}$, and $100 \mathrm{NaClO}$ ) treatment and combined treatment of aerosolization with 100 SAEW and UVC LED $(275 \mathrm{~nm})$ for reducing populations of EHEC and $S$. aureus in soft fresh produce was investigated. The highest reductions in EHEC and $S$. aureus populations in strawberries, baby leaves, and sliced onions were observed with the combined treatment of aerosolization of 100 ppm SAEW and UVC LED. The combined treatment further reduced EHEC and $S$. aureus populations in strawberries during 7 days of storage at 10 and $15^{\circ} \mathrm{C}$. Growths of EHEC and S. aureus in baby leaves and sliced onions were not inhibited during storage at $15^{\circ} \mathrm{C}$. However, the combined treatment group always showed lower populations than the untreated group (control) during 7 days of storage at 10 and $15^{\circ} \mathrm{C}$. In addition, less moisture loss was observed for strawberries with the combined treatment than for baby leaves and sliced onion during storage at 10 and $15{ }^{\circ} \mathrm{C}$. Overall, the combined treatment showed better maintenance of the color and visual appearance than the untreated group (control) for soft fresh produce during 7 days of storage at $10^{\circ} \mathrm{C}$ and $15^{\circ} \mathrm{C}$. Therefore, combined treatment of aerosolization with 100 SAEW and UVC LED could enhance microbial safety and prolong the shelf life of soft fresh produce.

Author Contributions: Investigation, C.-L.L. and G.-H.K.; methodology, C.-L.L. and K.-S.Y.; project administration, K.-S.Y.; writing—original draft preparation, C.-L.L.; writing—review and editing, K.-S.Y. All authors have read and agreed to the published version of the manuscript.

Funding: This research was funded by Ministry of Food and Drug Safety, grant number 20162MFDS012.

Data Availability Statement: We did not report any additional data for this study.

Acknowledgments: This research was funded by the Ministry of Food and Drug Safety, grant number 20162MFDS012.

Conflicts of Interest: The authors declare no conflict of interest. 


\section{References}

1. Food Information Statistics System (FIS). Status of Processed Food Segment Markets 2019-Convenience Food Market. 2019. Available online: https:/ / www.Atfis.or.Kr/Article/M001050000/View.Do?ArticleId=3260\&page=2\&searchKey=\&searchString= \&searchCategory $=$ (accessed on 11 December 2020).

2. Statista (2020) Fresh-Food Meal-Kit Delivery Market Value U.S. 2016-2022. Available online: https://www.Statista.Com/ Statistics /761621/Meal-Kit-Delivery-Service-Market-Value/ (accessed on 14 January 2021).

3. Centers for Disease Control and Prevention (CDC). List of Selected Multistate Foodborne Outbreak Investigations. 2020. Available online: https://www.Cdc.Gov/Foodsafety/Outbreaks/Multistate-Outbreaks/Outbreaks-List.Html (accessed on 15 January 2021).

4. Huang, Y.; Ye, M.; Chen, H. Inactivation of Escherichia coli O157:H7 and Salmonella spp. in Strawberry Puree by High Hydrostatic Pressure with/without Subsequent Frozen Storage. Int. J. Food Microbiol. 2013, 160, 337-343. [CrossRef] [PubMed]

5. Luna-Gierke, R.E.; Griffin, P.M.; Gould, L.H.; Herman, K.; Bopp, C.A.; Strockbine, N.; Mody, R.K. Outbreaks of Non-O157 Shiga Toxin-Producing Escherichia coli Infection: USA. Epidemiol. Infect. 2014, 142, 2270-2280. [CrossRef] [PubMed]

6. Eurosurveillance. National Outbreak of Shiga Toxin-Producing Escherichia coli O157: H7 Linked to Mixed Salad Leaves, United Kingdom, 2016. 2018. Available online: https:/ / www.Eurosurveillance.Org/Content/10.2807/1560-7917.ES.2018.23.18.17-00197 (accessed on 16 January 2021).

7. Kozak, G.K.; MacDonald, D.; Landry, L.; Farber, J.M. Foodborne Outbreaks in Canada Linked to Produce: 2001 through 2009. J. Food Prot. 2013, 76, 173-183. [CrossRef]

8. Kim, S.R.; Chu, H.J.; Yi, S.W.; Jang, Y.J.; Shim, W.B.; Nguyen, B.H.; Kim, W.-I.; Kim, H.J.; Ryu, K. Investigation of Hazardous Microorganisms in Baby Leafy Vegetables Collected from a Korean Market and Distribution Company. J. Food Hyg. Saf. 2019, 34, 526-533. [CrossRef]

9. Tango, C.N.; Wei, S.; Khan, I.; Hussain, M.S.; Kounkeu, P.F.N.; Park, J.; Kim, S.; Oh, D.H. Microbiological Quality and Safety of Fresh Fruits and Vegetables at Retail Levels in Korea. J. Food Sci. 2018, 83, 386-392. [CrossRef] [PubMed]

10. Song, B.R.; Kim, S.H.; Kim, J.K.; Han, J.A.; Kwak, H.S.; Chung, K.T.; Heo, E.J. Establishment of Microbial Criteria by Investigation of Microbial Contamination in Ready-to-Eat Foods. J. Food Hyg. Saf. 2017, 32, 348-354. [CrossRef]

11. Kim, W.I.; Gwak, M.; Jo, A.R.; Ryu, S.D.; Kim, S.R.; Ryu, S.H.; Kim, H.Y.; Ryu, J.G. Investigation of Microbiological Safety of on-farm Produce in Korea. J. Food Hyg. Saf. 2017, 32, 20-26. [CrossRef]

12. Quansah, J.K.; Gazula, H.; Holland, R.; Scherm, H.; Li, C.; Takeda, F.; Chen, J. Microbial Quality of Blueberries for the Fresh Market. Food Control 2019, 100, 92-96. [CrossRef]

13. Di Gioia, F.; Renna, M.; Santamaria, P. Sprouts, Microgreens and “Baby Leaf" Vegetables. In Minimally Processed Refrigerated Fruits and Vegetables; Yildiz, F., Wiley, R.C., Eds.; Food Engineering Series; Springer: Boston, MA, USA, 2017; pp. 403-432. ISBN 978-1-4939-7018-6.

14. Lee, H.O.; Kim, J.Y.; Yoon, D.H.; Cha, H.S.; Kim, G.H.; Kim, B.S. Microbial Contamination in a Fresh-Cut Onion Processing Facility. Korean J. Food Preserv. 2009, 16, 567-572.

15. Abadias, M.; Usall, J.; Anguera, M.; Solsona, C.; Viñas, I. Microbiological Quality of Fresh, Minimally-Processed Fruit and Vegetables, and Sprouts from Retail Establishments. Int. J. Food Microbiol. 2008, 123, 121-129. [CrossRef] [PubMed]

16. Liu, F.; Li, Y. Storage Characteristics and Relationships between Microbial Growth Parameters and Shelf Life of MAP Sliced Onions. Postharvest Biol. Technol. 2006, 40, 262-268. [CrossRef]

17. Jiang, Y.; Fan, X.; Li, X.; Gurtler, J.B.; Mukhopadhyay, S.; Jin, T. Inactivation of Salmonella Typhimurium and Quality Preservation of Cherry Tomatoes by In-Package Aerosolization of Antimicrobials. Food Control 2017, 73, 411-420. [CrossRef]

18. Park, S.H.; Kang, D.H. Combination Treatment of Chlorine Dioxide Gas and Aerosolized Sanitizer for Inactivating Foodborne Pathogens on Spinach Leaves and Tomatoes. Int. J. Food Microbiol. 2015, 207, 103-108. [CrossRef] [PubMed]

19. Choi, M.R.; Lee, S.Y.; Park, K.H.; Chung, M.S.; Ryu, S.R.; Kang, D.H. Effect of Aerosolized Malic Acid against Listeria monocytogenes, Salmonella Typhimurium, and Escherichia coli O157:H7 on Spinach and Lettuce. Food Control 2012, 24, 171-176. [CrossRef]

20. Oh, S.W.; Dancer, G.I.; Kang, D.H. Efficacy of Aerosolized Peroxyacetic Acid as a Sanitizer of Lettuce Leaves. J. Food Prot. 2005, 68, 1743-1747. [CrossRef] [PubMed]

21. Franz, C.M.A.P.; Specht, I.; Cho, G.S.; Graef, V.; Stahl, M.R. UV-C-Inactivation of Microorganisms in Naturally Cloudy Apple Juice Using Novel Inactivation Equipment Based on Dean Vortex Technology. Food Control 2009, 20, 1103-1107. [CrossRef]

22. Guerrero-Beltr·n, J.A.; Barbosa-C.novas, G.V. Advantages and Limitations on Processing Foods by UV Light. Food Sci. Technol. Int. 2004, 10, 137-147. [CrossRef]

23. Green, A.; Popović, V.; Warriner, K.; Koutchma, T. The Efficacy of UVC LEDs and Low Pressure Mercury Lamps for the Reduction of Escherichia coli O157:H7 and Listeria monocytogenes on Produce. Innov. Food Sci. Emerg. Technol. 2020, 64, 102410. [CrossRef]

24. Selin, H.; Keane, S.E.; Wang, S.; Selin, N.E.; Davis, K.; Bally, D. Linking Science and Policy to Support the Implementation of the Minamata Convention on Mercury. Ambio 2018, 47, 198-215. [CrossRef]

25. Green, A.; Popović, V.; Pierscianowski, J.; Biancaniello, M.; Warriner, K.; Koutchma, T. Inactivation of Escherichia coli, Listeria and Salmonella by Single and Multiple Wavelength Ultraviolet-Light Emitting Diodes. Innov. Food Sci. Emerg. Technol. 2018, 47, 353-361. [CrossRef]

26. Shin, J.Y.; Kim, S.J.; Kim, D.K.; Kang, D.H. Fundamental Characteristics of Deep-UV Light-Emitting Diodes and Their Application to Control Foodborne Pathogens. Appl. Environ. Microbiol. 2016, 82, 2-10. [CrossRef] [PubMed] 
27. Würtele, M.A.; Kolbe, T.; Lipsz, M.; Külberg, A.; Weyers, M.; Kneissl, M.; Jekel, M. Application of GaN-Based Ultraviolet-C Light Emitting Diodes-UV LEDs-For Water Disinfection. Water Res. 2011, 45, 1481-1489. [CrossRef] [PubMed]

28. Lee, J.Y.; Yang, S.Y.; Yoon, K.S. Control Measures of Pathogenic Microorganisms and Shelf-Life Extension of Fresh-Cut Vegetables. Foods 2021, 10, 655. [CrossRef]

29. Jiang, Y.; Ai, C.; Liao, X.; Liu, D.; Ding, T. Effect of Slightly Acidic Electrolyzed Water (SAEW) and Ultraviolet Light Illumination Pretreatment on Microflora Inactivation of Coriander. LWT 2020, 132, 109898. [CrossRef]

30. Kim, D.K.; Kang, D.H. Inactivation Efficacy of a Sixteen UVC LED Module to Control Foodborne Pathogens on Selective Media and Sliced Deli Meat and Spinach Surfaces. LWT 2020, 130, 109422. [CrossRef]

31. Seong, J.Y.; Kwon, K.H.; Oh, S.W. Combined Effect of Aerosolized Malic Acid and UV-C for the Inactivation of Escherichia coli O157:H7, Salmonella Typhimurium, and Listeria monocytogenes on Fresh-Cut Lettuce. J. Food Saf. 2017, 37, e12359. [CrossRef]

32. Kim, S.J.; Kim, D.K.; Kang, D.H. Using UVC Light-Emitting Diodes at Wavelengths of 266 to 279 Nanometers to Inactivate Foodborne Pathogens and Pasteurize Sliced Cheese. Appl. Environ. Microbiol. 2016, 82, 11-17. [CrossRef] [PubMed]

33. Kim, J.H.; Ro, E.Y.; Yoon, K.S. Comparison of Growth Kinetics of Various Pathogenic E. coli on Fresh Perilla Leaf. Foods 2013, 2, 364-373. [CrossRef]

34. Cho, J.L.; Kim, C.K.; Park, J.Y.; Kim, J.M. Efficacy of Aerosolized Chlorine Dioxide in Reducing Pathogenic Bacteria on Washed Carrots. Food Sci. Biotechnol. 2017, 26, 1129-1136. [CrossRef] [PubMed]

35. Kim, S.O.; Ha, J.W.; Park, K.H.; Chung, M.S.; Kang, D.H. Infrared Sensor-Based Aerosol Sanitization System for Controlling Escherichia coli O157:H7, Salmonella Typhimurium, and Listeria monocytogenes on Fresh Produce. J. Food Prot. 2014, 77, 977-980. [CrossRef] [PubMed]

36. Kim, H.S.; Choi, S.J.; Yoon, K.S. Efficacy Evaluation of Control Measures on the Reduction of Staphylococcus aureus in Salad and Bacillus cereus in Fried Rice Served at Restaurants. Foodborne Pathog. Dis. 2017, 15, 198-209. [CrossRef]

37. Ministry of Food and Drug Safety (MFDS). A Study on Improvement of Usage Standards for Food Sanitizers (Chlorine Dioxide, Sodium Hypochlorite). 2018. Available online: https:/ / scienceon.kisti.re.kr/srch/selectPORSrchReport.do?cn=TRKO201900003 485 (accessed on 18 July 2021).

38. Han, R.; Liao, X.; Ai, C.; Ding, T.; Wang, J. Sequential Treatment with Slightly Acidic Electrolyzed Water (SAEW) and UVC Light-Emitting Diodes (UVC-LEDs) for Decontamination of Salmonella Typhimurium on Lettuce. Food Control 2021, $123,107738$. [CrossRef]

39. Lee, J.H.; Chun, H.H.; Oh, D.H.; Park, J.Y.; Won, M.S.; Song, K.B. Sensory and Microbiological Qualities of Romaine Lettuce and Kale Affected by a Combined Treatment of Aqueous Chlorine Dioxide and Ultraviolet-C. Hort. Environ. Biotechnol. 2012, 53, 387-396. [CrossRef]

40. Moreno, C.; Andrade-Cuvi, M.J.; Zaro, M.J.; Darre, M.; Vicente, A.R.; Concellón, A. Short UV-C Treatment Prevents Browning and Extends the Shelf-Life of Fresh-Cut Carambola. J. Food Qual. 2017, 2017, e2548791. [CrossRef]

41. Hörtensteiner, S. Chlorophyll breakdown in higher plants and algae. Cell. Mol. Life Sci. 1999, 56, 330-347. [CrossRef]

42. Matile, P.; Hörtensteiner, S.; Thomas, H. Chlorophyll degradation. Annu. Rev. Plant Biol. 1999, 50, 67-95. [CrossRef]

43. Nimitkeatkai, H.; Kim, J.G. Washing Efficiency of Acidic Electrolyzed Water on Microbial Reduction and Quality of 'Fuji' Apples. Kor. J. Hort. Sci. Technol. 2009, 27, 250-255.

44. Massey, L.M.; Hettiarachchy, N.S.; Martin, E.M.; Ricke, S.C. Electrostatic Spray of Food-Grade Organic Acids and Plant Extract to Reduce Escherichia coli O157:H7 on Fresh-Cut Cantaloupe Cubes. J. Food Saf. 2013, 33, 71-78. [CrossRef]

45. Lee, C.L.; Kim, Y.H.; Ha, S.D.; Yoon, Y.H.; Yoon, K.S. Risk assessment of Staphylococcus aureus infection in ready-to-eat SamgakKimbap. Korean J. Food Sci. Technol. 2020, 52, 661-669. [CrossRef]

46. Nunes, M.C.N.; Brecht, J.K.; Morais, A.M.B.; Sargent, S.A. Possible Influences of Water Loss and Polyphenol Oxidase Activity on Anthocyanin Content and Discoloration in Fresh Ripe Strawberry (Cv. Oso Grande) During Storage at $1{ }^{\circ}$ C. J. Food Sci. 2005, 70, S79-S84. [CrossRef]

47. Jalali, A.; Linke, M.; Geyer, M.; Mahajan, P.V. Shelf-Life Prediction Model for Strawberry Based on Respiration and Transpiration Processes. Food Packag. Shelf Life 2020, 25, 100525. [CrossRef]

48. Nalbandi, H.; Seiiedlou, S. Sensitivity Analysis of the Precooling Process of Strawberry: Effect of Package Designing Parameters and the Moisture Loss. Food Sci. Nutr. 2020, 8, 2458-2471. [CrossRef]

49. Ahmed, W.; Butt, M.S. Preserving Strawberry (Fragaria Ananasa) Using Alginate and Soy Based Edible Coatings. Am. J. Food Technol. 2014, 2, 158-161. [CrossRef]

50. de Souza, V.R.; Popović, V.; Warriner, K.; Koutchma, T. A Comparative Study on the Inactivation of Penicillium Expansum Spores on Apple Using Light Emitting Diodes at $277 \mathrm{~nm}$ and a Low-Pressure Mercury Lamp at $253.7 \mathrm{~nm}$. Food Control 2020, 110, 107039. [CrossRef]

51. Funamoto, Y.; Yamauchi, N.; Shigenaga, T.; Shigyo, M. Effects of heat treatment on chlorophyll degrading enzymes in stored broccoli (Brassica oleracea L.). Postharvest Biol. Technol. 2002, 24, 163-170. [CrossRef]

52. Chairat, B.; Nutthachai, P.; Varit, S. Effect of UV-C Treatment on Chlorophyll Degradation, Antioxidant Enzyme Activities and Senescence in Chinese Kale (Brassica Oleracea Var. Alboglabra). Int. Food Res. J. 2013, 20, 623-628.

53. Costa, L.; Vicente, A.R.; Civello, P.M.; Chaves, A.R.; Martínez, G.A. UV-C Treatment Delays Postharvest Senescence in Broccoli Florets. Postharvest Biol. Technol. 2006, 39, 204-210. [CrossRef] 